\title{
A comparison of early Neolithic crop and weed assemblages from the Linearbandkeramik and the Bulgarian Neolithic cultures: differences and similarities
}

Received: 13 October 2004 / Accepted: 30 March 2005 / Published online: 25 August 2005

(C) Springer-Verlag 2005

\begin{abstract}
The spread of early agriculture from the Mediterranean to central Europe is still poorly understood. The new subsistence reached western central Europe during the second half of the 6th millennium cal B.c. This paper presents a comparison of crop and weed species from 33 Bandkeramik sites from Austria and Germany and six Bulgarian Neolithic sites. The aim is to investigate whether the early cultivation system brought in from the eastern Mediterranean was adapted to European conditions in Bulgaria or further West. Some characteristics of the potential weeds are interpreted with respect to the cultivation systems and the origin of the species.
\end{abstract}

Keywords Early Neolithic · Bulgaria - Germany · Austria $\cdot$ Cultivation systems $\cdot$ Weeds

\section{Introduction}

The introduction of early agriculture to central Europe is still not known in detail. The first "station" during the spread of this new subsistence outside the eastern Mediterranean is represented by the Early Neolithic of Bulgaria at the beginning of the 6th millennium cal B.C. The Bulgarian Neolithic lasted for about eleven hundred years (about 6000 to 4900 cal B.C.; Görsdorf and Bojadžiev 1996). The new subsistence reached western central Europe during the second half of the 6th millennium cal B.c. (Lüning 2000, p 5ff.; Stäuble 1995; Stöckli 2002, p 55). There, the earliest agricultural finds are of the Bandkeramik culture, also called Linearbandkeramik or

\footnotetext{
A. Kreuz $(\bowtie) \cdot$ E. Schäfer · J. Wiethold

Landesamt für Denkmalpflege Hessen,

Sachgebiet Naturwissenschaften,

Schloß Biebrich/Ostflügel, D-65203 Wiesbaden

e-mail: a.kreuz@denkmalpflege-hessen.de

E. Marinova

Sofia University "Sv. Kliment Ohridski”,

Department of Botany,

8 Dragan Tzankov blv., BG-1164 Sofia, Bulgaria
}

LBK (Fig. 1). The changing ornamental style of the pottery allowed a differentiation of both cultures into phases (for the Bandkeramik, Meier-Arendt 1966; for the Bulgarian Neolithic see, for example Georgiev 1981; Nikolov 2000, 2002, 2004). For the following comparison it is important that the Late Neolithic of Bulgaria is contemporary with the whole Bandkeramik period (about 5400 to 4900 cal B.c.). The earliest Bandkeramik phase I lasted for about half the time span of the whole Bandkeramik culture (Stäuble 1995; Stöckli 2002, p 55).

From recent excavations in Bulgaria new archaeobotanical evidence is available (Marinova 2000, 2001; Marinova et al. 2002; Popova 1995a, b; Thanheiser 1997). It allows a comparison of agricultural data from the Bulgarian Neolithic with that of the early Neolithic in Germany and Austria. This comparison offers the opportunity to investigate whether the early cultivation system brought in from Turkey and Greece was adapted to European conditions in Bulgaria or further West. The spread of the Neolithic to the western Mediterranean is not discussed in this paper.

\section{Archaeological evidence}

The Karanovo Culture, named after the famous tell site at the border of the Thracian plain, became a synonym for the Neolithic and Chalcolithic of Bulgaria (Fig. 1). Today, different regional groups are differentiated. They all have in common a similar settlement structure and architecture as well as a red-slipped pottery with white, later dark red, ornamentation (Georgiev 1981; Lichardus-Itten et al. 2002; Nikolov 2000, 2002, 2004; Todorova 1981). In addition some early groups apparently produced monochromatic pottery (for a critical review see LichardusItten and Lichardus 2003). In the following we will use the terms Early, Middle and Late Bulgarian Neolithic to avoid these group names.

The first farmers of Bulgaria settled in the foothills around the Thracian plain and in those of south-western Bulgaria. Possibly the Struma valley played an important 
Fig. 1 Archaeological cultures at the beginning of the Neolithic from the Near East to western central Europe. Indicated are the area of the Bandkeramik culture at its maximum extension and the area of the Bulgarian Neolithic Karanovo culture and the Starčevo-KörösCris complex (modified from Raetzel-Fabian 1988, Fig. 15)

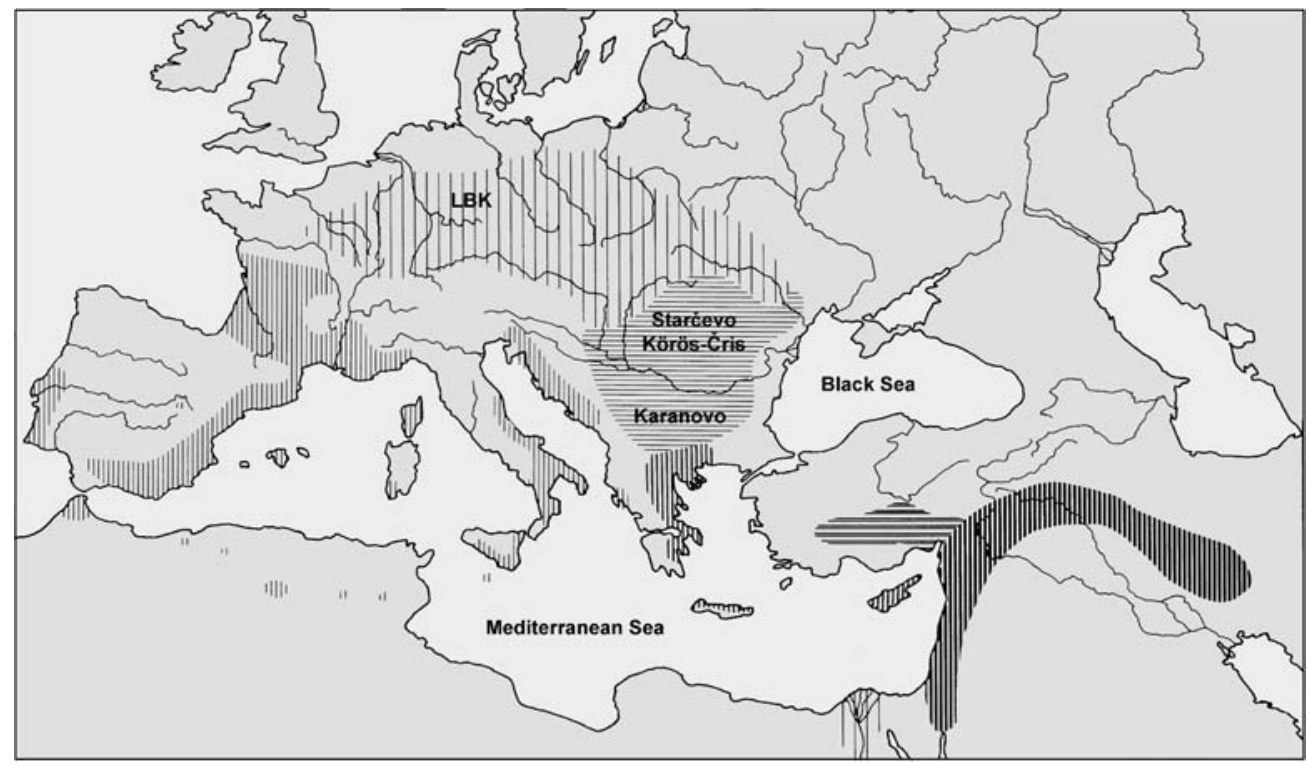

role during the introduction of Neolithic subsistence from Thessaly to Bulgaria (Perles 2001; Nikolov 2004). It is still a matter of dispute whether the new subsistence arrived from Greece exclusively or from Anatolia via Turkish Thrace or from both regions (for example Parzinger 1993, p 84). The state of research does not allow a final statement concerning this question. Recent excavations, for example at the Early Neolithic site of Yabalkovo at the southern border of the Bulgarian part of the Thracian plain, will provide new insights into this subject (K. Leshtakov personal communication).

Finds of the earliest Bandkeramik have been made in a huge area of western central Europe. In the second part of the Bandkeramik from phase II to phase V (chronological phases based on the pottery after Meier-Arendt 1966) the distribution area became even larger (Lüning 2000). Finds and settlements are spread between the Paris Basin and the Black Sea (Fig. 1).

Archaeological and botanical evidence points to western Hungary as the centre of Bandkeramik origin. This Hungarian Bandkeramik culture was possibly strongly influenced by the Neolithic Starčevo-Köros-Čris complex of eastern Hungary, Serbia and Romania (Fig. 1; Bánffy 2001; Kalicz 2001; Lichardus-Itten and Lichardus 2003; Lüning 1991, 2000; Lüning et al. 1989).

Similarities and differences of both the Bandkeramik and the Bulgarian Neolithic cultures are reflected for example by the structures of settlements and buildings. In both early Neolithic cultures the houses were built with a timber framework. This is an important difference to the mud-brick houses of Greece and Turkey (Parzinger 1993, pp 294ff.; Perles 2001, pp 172ff.). The Bandkeramik sites are open flat settlements each comprising just a few houses. The houses were about $30 \mathrm{~m}$ long and $6 \mathrm{~m}$ wide. There are postholes and wall-ditches as well as some pits (see papers in Eckert et al. 2003), but the ground surface is eroded, so that the house floors are not preserved. In contrast to the Bandkeramik, the Bulgarian Neolithic sites are either multilayer flat settlements or tell sites (Georgiev 1961, 1981; Hiller 1993; Lichardus-Itten et al. 2002; Todorova 1981, Todorova and Vaissov 1993). It is still open to discussion why some Neolithic settlements in Bulgaria stopped gaining height before becoming a real tell.

In both areas botanical material can be recovered from rubbish pits. In addition, in Bulgaria, culture layers of levelled houses as well as ground floors of buildings and their surroundings are preserved in situ as they have been covered by layers of settlement waste. The latter are the places where the storage finds or other massive concentrations of plant remains can be found, if the house had burnt down (Dennell 1978; Dotcheva 1990; Marinova 2001; Thanheiser 1997; Tschakalova and Božilova 2002; Tschakalova and Sârbinska 1986).

In contrast to Bandkeramik settlements characterized by single standing long-houses, the Bulgarian Neolithic villages consist of rows of houses (Georgiev 1961, 1981; Hiller 1993; Lichardus-Itten et al. 2002; Todorova 1981, Todorova and Vaissov 1993). The Bulgarian Neolithic rectangular houses were about one third the size of the Bandkeramik long-houses. All these differences have important social implications (Parzinger 1993, p 295). They could imply for example different family or group sizes and structures.

\section{Ecological conditions}

The first farmers of both cultures - the Bulgarian Neolithic and the Bandkeramik - settled in landscapes very well suited for agriculture. In Bulgaria these are mostly regions with brown soils (Cambisols) and a subMediterranean to sub-continental climate. Present-day average mean temperature covers the range between 10 and $14^{\circ} \mathrm{C}$, average precipitation-with two maxima, the main in May/June and a secondary one in November/ 


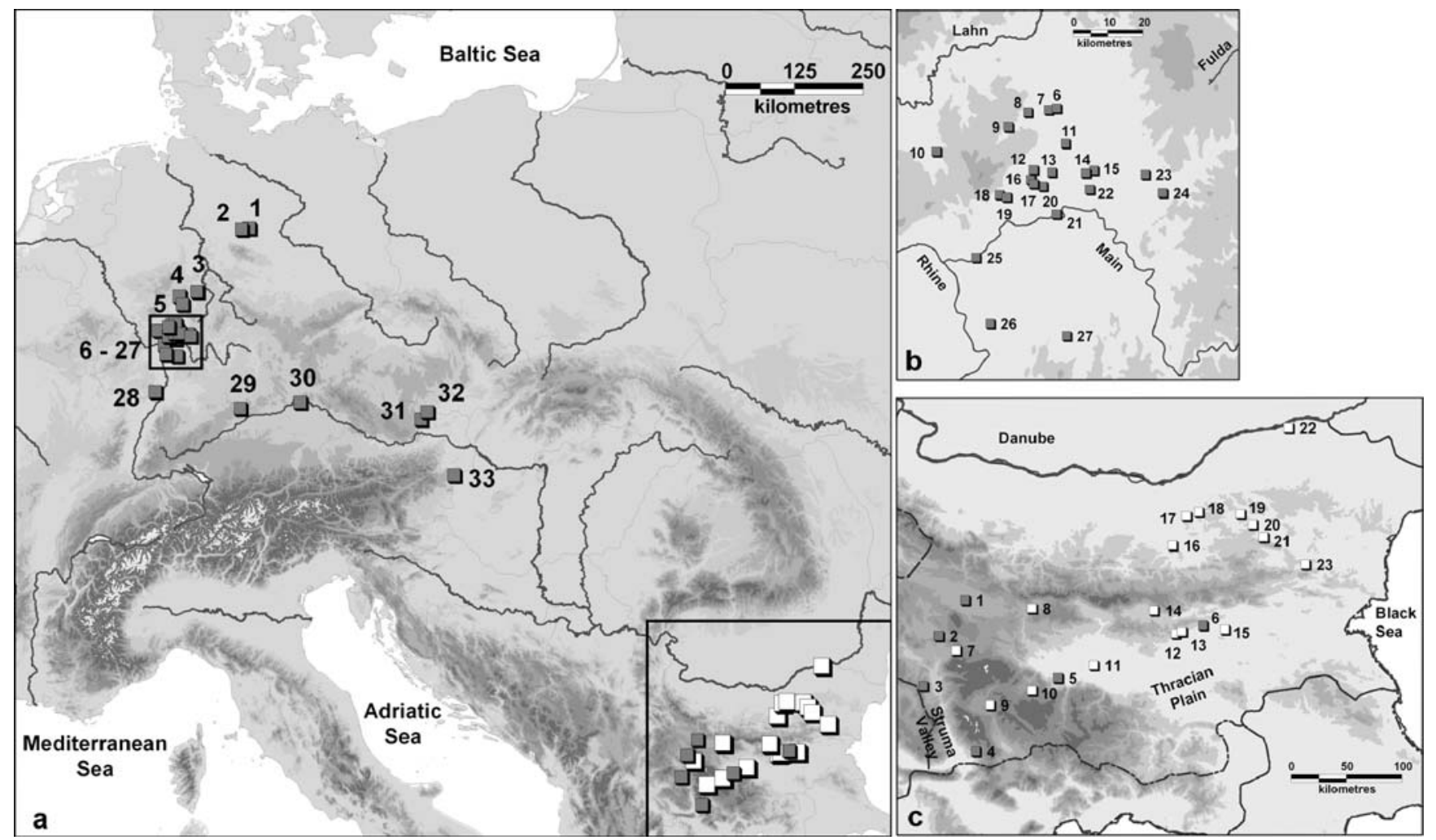

Fig. 2 German and Austrian Bandkeramik and Bulgarian Neolithic sites mentioned in the text. a, b Archaeobotanically investigated Bandkeramik sites in Germany and Austria. Northern Harz area: 1 Eitzum, 2 Klein Denkte; Hessen: 3 Wernswig, 4 Bracht, 5 Mardorf 23, 6 Steinfurth, 7 Nieder-Mörlen, 8 Fauerbach, 9 Usingen, 10 Würges, 11 Bruchenbrücken, 12 Ober-Erlenbach, 13 Kloppenheim, 14 Windecken, 15 Ostheim, 16 and 17 Nieder-Eschbach (AK2, AK123), 18 Kronberg, 19 Niederhöchstadt, 20 Harheim, 21 Fechenheim, 22 Mittelbuchen, 23 Niedergründau, 24 Hailer, 25 Raunheim, 26 Goddelau, 27 Wembach-Hahn; Pfalz (Palatinate): 28 Herxheim; Nördlinger Ries: 29 Enkingen; Danube valley: 30

December-between 500 and $700 \mathrm{~mm}$ (Egger 1997; Horvat et al. 1974; N. Ninov 2002; Velev 2002; Kopralev 2002).

In Germany and Austria the landscapes settled first were mostly characterized by Chernozem soils, developed from loess or fluvial sediments, and by today's warm and dry climate. Present-day average mean temperature lies between 7 and $9^{\circ} \mathrm{C}$, average precipitation - with a maximum during (June/)July/August-between 550 and 650 mm (Bakels 1978; Kreuz 1990, p 7ff.; Lüning 2000; Sielmann 1971). High lake levels could be interpreted as signs of a wetter climate in central Europe at that time. This might have been induced by precipitation, possibly in form of heavy rainfalls (Beug et al. 1999; Bouzek 2001; Haas et al. 1998; Hormes et al. 2001; Kalis et al. 2003; Kreuz 1990, p 8; Magny 1998; Maise 1998; Schmidt and Gruhle 2003; Spurk et al. 2002).

The reconstruction of the temperatures around 6000 B.C. suggests that in south-eastern Europe the mean winter temperatures might have been almost at today's level and the summer temperatures were slightly lower than today.
Mintraching; Waldviertel/ Austria: 31 Rosenburg, 32 Strögen; Burgenland/Austria: 33 Neckenmarkt. c Archaeobotanically investigated Neolithic sites in Bulgaria. Sites studied by E. Marinova are indicated in grey. 1 Slatina, 2 Gâlâbnik, 3 Drenkovo Plosteko, 4 Kovačevo, 5 Kapitan Dimitrievo, 6 Karanovo, 7 Sapareva Banya Kremenik, 8 Čavdar, 9 Elešnica, 10 Rakitovo, 11 Yassa Tepe, 12 Okrâžna bolnica, 13 Azmak, 14 Kazanlâk, 15 Ezero, 16 Samovodene, 17 Orlovec, 18 Koprivec, 19 Drinovo, 20 Podgorica, 21 Poljanica Platoto, 22 Malâk Preslavec, 23 Vesselinovo. For references see Table 1

Cooler and wetter conditions than today are discussed (Davis et al. 2003).

Landscapes of both areas have been reconstructed by palynologists and anthracologists as more or less densely wooded. As in central Europe, early Neolithic human impact is difficult to trace by pollen analysis in Bulgaria, as there are only weak signals indicating cultivation. In both regions this might be due to the fact that the deposits analyzed are not adjacent to the settlements and fields, and the former woodland canopy had acted as a pollen filter.

In Bulgaria, pollen diagrams are available from the hilly zones and the higher mountain areas. Only very few diagrams cover the early and middle Holocene (e.g. Božilova et al. 1996; Huttunen et al. 1992; Filipovitch 1996; Filipovitch and Lazarova 2001, p 170, Fig. 2; Stefanova and Ammann 2003; Tonkov and Božilova 1992). The regions settled by the first farmers were dominated by thermophilous to mesophilous and submediterranean to subcontinental bitter oak forests as well as mixed forests with Quercus cerris, $Q$. petraea, $Q$. 
Table 1 Archaeobotanical studies of 23 Neolithic sites in Bulgaria (after Marinova 2001). Numbers refer to the location of the sites in Fig. 2c; for references see the bibliography

\begin{tabular}{ll}
\hline Early Bulgarian Neolithic 1 & \\
Azmak (13) & Hopf 1973 \\
Elešnica (9) & Dotcheva unpubl. \\
Gâlâbnik (2) & Marinova et al. 2002 \\
Karanovo (6) & Arnaudov 1938; Thanheiser 1997 \\
Koprivec (18) & Marinova unpublished \\
Kovačevo (4) & Popova 1992; Thiébault 1997; \\
& Marinova 2000 \\
Orlovec (17) & Marinova unpublished \\
Poljanica Platoto (21) & Hopf 1988 \\
Slatina (1) & Dotcheva 1990
\end{tabular}

Early Bulgarian Neolithic 2 Azmak (13)

Čavdar (8)

Kapitan Dimitrievo (5)

Karanovo (6)

Kovačevo (4)

Malâk Preslavec (22)

Okrâžna Bolnica (12)

Rakitovo (10)

Sapareva Banya/Kremenik (7) Slatina (1)

Middle Bulgarian Neolithic

Karanovo (6)
Kazanlâk (14)
Samovodene (16)
Late Bulgarian Neolithic
Azmak (13)
Drenkovo-Ploshteko (3)
Drinovo (19)
Ezero (15)
Kapitan Dimitrievo (5)
Karanovo (6)

Kazanlâk (14)

Podgorica (20)

Samovodene (16)

Vesselinovo (23)

Yassa tepe (11)

\section{Hopf 1973}

Hopf 1973; Dennel 1978

Arnaudov 1949; Hopf 1973; Marinova 1999, 2001

Hopf 1973; Renfrew 1973; Thanheiser 1997

Marinova 2000, 2001

Panayotov et al. 1992

Lisitzyna and Lestnikova unpubl. in Lisitzyna and Filipovitch 1980

Tschakalova and Božilova 2002

Tschakalova and Sârbinska 1986

Marinova 2001

Hopf 1973; Marinova 2001, 2002

Hopf 1973

Marinova unpublished

Hopf 1973; Renfrew 1979

Marinova 2001

Popova 1995b

Hopf 1973

Arnaudov 1936; Arnaudov and Vassileva 1948; Popova 1995a; Thanheiser 1997; Marinova 2001, 2002

Hopf 1973; Dennel 1978

Popova 1995b

Marinova unpublished

Arnaudov 1936

Hopf 1973; Renfrew 1973
Marinova 1999, 2001

frainetto, Q. pubescens, Carpinus orientalis and Fraxinus ornus (see also Bohn et al. 2003, "Klimatyp VI").

In Germany and Austria, the forest cover was also formed by deciduous woodland of comparable species to those in Bulgaria like Quercus petraea and Q. robur, Fraxinus excelsior, Ulmus sp., Tilia sp. Acer sp. and

others (Bakels 1978; Beug 1986, 1992; Kreuz 1990 pp 17ff., 1995, in press a; Liese-Kleiber 1997; Litt 1990; Schäfer 1996; Schweizer 2001; Van Zeist 1967; Van Zeist and Van der Spoel-Walvius 1980). There are different opinions concerning for example the percentages of Quercus (oak) and Tilia (lime) trees and other woodland species or the kind of woodland cover of the flood plains, but this subject is not of interest here. In our investigation areas, the forest cover on Chernozems was formed by deciduous woodland. The results of charcoal analysis can be interpreted as managed hedges serving as supply of firewood (Groenman-van Waateringe 1970; Kreuz 1988, 1992).

Archaeozoological investigations from settlements of both cultures revealed that the spectra of domestic and wild animal species are comparable (Arbogast et al. 2001; Benecke and Ninov 2002; Kovachev and Georgiev 2002; Ninov 1992, 1999). It is difficult to estimate what was the main domestic animal at the different sites. This is due to the fact that preservation of bones differs not only between sites but also within one single excavation area due to changing soil conditions. It has to be stressed that there is no dominance of sheep or goat detectable in either region.

\section{Archaeobotanical dataset}

In Bulgaria, 23 Neolithic sites have been investigated archaeobotanically to date (Fig. 2c; for references see Table 1). The assemblages of crops are almost identical at the different sites. The following calculations are based on the data available from six recent excavations (Table 2). Some weed taxa were not included, because their occurrence in Neolithic sites from Bulgaria needs to be confirmed.

Figures $2 \mathrm{a}$ and $\mathrm{b}$ show the location of the 33 Bandkeramik settlement sites investigated archaeobotanically. Determinations have been carried out by Nicole Boenke (Götzis, Austria), Angela Kreuz, Elena Marinova, Ursula Thanheiser (Wien, Austria) and Julian Wiethold. The data from Hesse, northern and southern Germany and southwestern Austria are methodologically comparable to each other. Therefore all data have been included in the following evaluation which has been carried out with the help of our archaeobotanical database programme ArboDat (Kreuz and Schäfer 2002; for the explanation of terms see also there). As it is often difficult to differentiate the Bandkeramik phases III to $\mathrm{V}$ based on fragmentary pottery finds, we combined the archaeobotanical results into one later Bandkeramik group LBK III-V. Features which could not be dated archaeologically more exactly than phases 'LBK IIff.' or 'LBK II/III' are not included in the calculations.

Due to the soil conditions in settlements of both cultures plant remains are preserved by charring or mineralization only. The contexts sampled at the Bulgarian Neolithic sites are often not "real" archaeological features but parts of bigger stratigraphic units such as layers or 


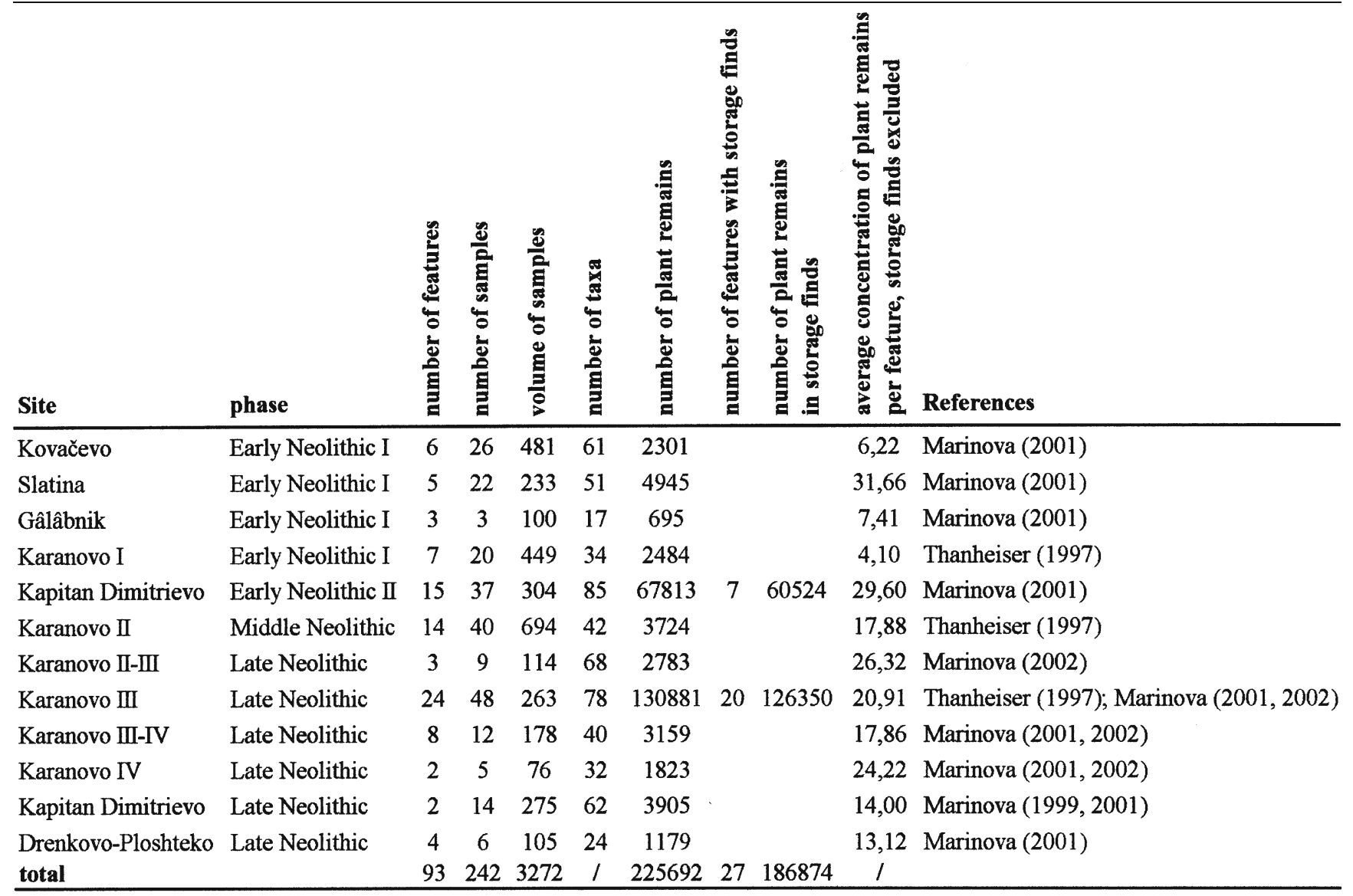

floors. There the squares excavated were taken as context units or "features".

Sample contents from both cultures represent something called "background or noise" (Bakels 1991, p 281). There are always charred mixtures of crop remains of several species and of by-products and waste. In the case of so-called storage finds we are possibly dealing with residues of accidents caused by fire. Storage finds occur in 27 Bulgarian Neolithic and two Bandkeramik features (Tables 2 and 3). Due to the occurrence of storage finds there, the number of plant remains identified is comparatively high at the Bulgarian sites (Table 2).

It has to be mentioned that post-holes and ditches contain very few or mostly no plant remains at Bandkeramik sites. Their density of plant remains is not comparable with that of pits, which-in their last function-were used for deposition of settlement waste. Therefore concentration values are based on samples from pits only (Table 3 ) and are always calculated without storage finds (66 Bulgarian Neolithic, 458 Bandkeramik features). The other calculations are based on samples from 93 Bulgarian Neolithic and 494 Bandkeramik features (see Tables 2 and 3).

Figure $3 \mathrm{a}$ shows the average concentration of plant remains per feature or context calculated for Bulgarian Neolithic and Bandkeramik sites. Grey bars represent only seeds, white bars show values for chaff. The apparently low average concentration values of chaff from both regions are similar to those from Iron Age and Roman sites in Hessen (Kreuz in press b), so they are "normal" within a usually observed range. On the contrary, it is only in Bandkeramik phase II and to a certain degree phases III-V that the values are extremely high (see also Fig. 3b; for the discussion see Kreuz in press a).

Surprisingly, the seed concentrations of the two areas resemble each other. Extremely low seed concentration values occur only at sites of Bandkeramik phase I (Fig. 3a). Due to unknown reasons, fewer charred seeds were deposited in pits at that time.

The samples are rarely sufficiently rich in crops and weeds for statistical analysis. In addition they almost never derive from a single crop species or crop processing stage. So we are dealing with mixtures of crop remains and by-product material, waste and residues caused by accidents involving fire which were found in open contexts. For all these reasons and due to the different state of research and the different datasets of our Bandkeramik and Bulgarian Neolithic sites, the following comparison has to be more of a qualitative character. 
Table 3 The archaeobotanical dataset from 33 Bandkeramik sites according to the archaeobotanical database program ArboDat in Germany and Austria used in this study. Numbers refer to the location of the sites in Fig. 2a, b. Plant codes of taxa are counted

\begin{tabular}{|c|c|c|c|c|c|c|c|c|c|c|c|c|c|}
\hline Site code & site & 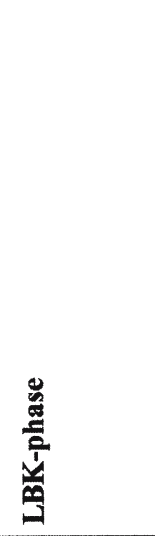 & 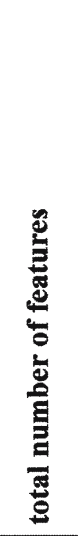 & 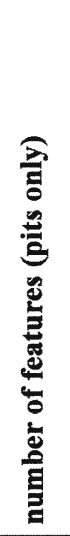 & 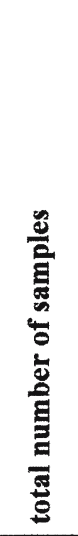 & 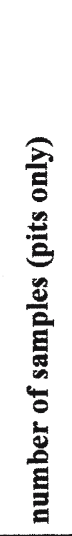 & 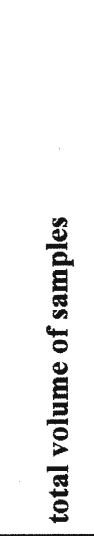 & 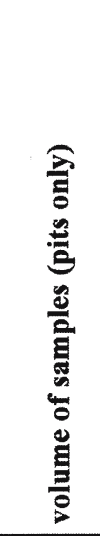 & 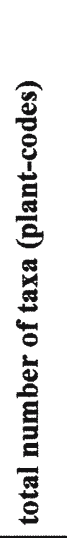 & 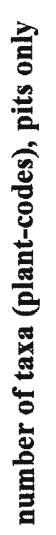 & 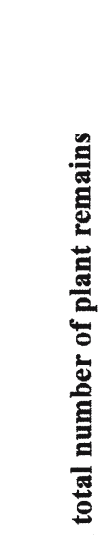 & 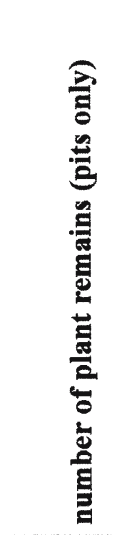 & 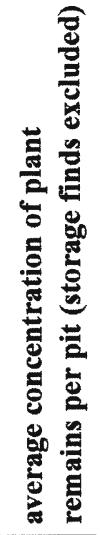 \\
\hline $\mathrm{AK} 1 \mathrm{BB}$ & Bruchenbrücken, Friedberg (11) & LBK I & 22 & 19 & 206 & 179 & 4127 & 3630 & 38 & 38 & 109113 & 109000 & 7,68 \\
\hline AK2 NES & Nieder-Eschbach, Frankfurt (17) & LBK I & 127 & 127 & 144 & 144 & 2799 & 2799 & 18 & 18 & 1341 & 1341 & 0,49 \\
\hline $\mathrm{AK} 3 \mathrm{GO}$ & Goddelau, Riedstadt (26) & LBK I & 5 & 5 & 67 & 67 & 1370 & 1370 & 16 & 16 & 5974 & 5974 & 1,36 \\
\hline AK7 SU2 & Steinfurth, Bad Nauheim (6) & LBK I & 3 & 3 & 59 & 59 & 811 & 811 & 23 & 23 & 5083 & 5083 & 3,75 \\
\hline $\mathrm{AK} 66 \mathrm{MB}$ & Mittelbuchen, Hanau (22) & LBK I & 6 & 6 & 12 & 12 & 158 & 158 & 17 & 17 & 217 & 217 & 1,04 \\
\hline AK167 NIO & Ostheim, Nidderau (15) & LBK I & 7 & 4 & 9 & 6 & 50 & 24 & 9 & 0 & 254 & 204 & 5,85 \\
\hline AK184 WÜ1 & Würges, Bad Camberg (10) & LBK I & 29 & 25 & 48 & 42 & 499 & 441 & 30 & 28 & 17501 & 17473 & 32,16 \\
\hline AK2001 EI 2 & Eitzum, Schöppenstedt (1) & LBK I & 6 & 3 & 113 & 108 & 2174 & 2101 & 34 & 34 & 17812 & 17606 & 7,52 \\
\hline AK2002 KD & Klein Der & LBK I & 3 & 3 & 19 & 10 & 320 & 320 & 7 & 7 & 87 & 87 & 0,23 \\
\hline AK2003 EN1 & Enkingen (29) & LBK I & 3 & 3 & 100 & 92 & 1742 & 1731 & 18 & 18 & 11076 & 11076 & 9,32 \\
\hline AK2004 MT1 & Mintraching (30) & LBK I & 2 & 2 & 107 & 106 & 1816 & 1816 & 23 & 23 & 373 & 373 & 0,19 \\
\hline AK2005 RB1 & Rosenburg (A) (31) & LBK I & 7 & 7 & 55 & 55 & 1100 & 1100 & 9 & 9 & 78 & 78 & 0,06 \\
\hline AK2006 ST1 & Strögen (A) (32) & LBK I & 7 & 7 & 37 & 37 & 695 & 695 & 7 & 7 & 62 & 62 & 0,04 \\
\hline AK2007 NM1 & Neckenmarkt (A) (33) & LBK I & 4 & 4 & 32 & 32 & 772 & 772 & 13 & 13 & 1932 & 1932 & 2,31 \\
\hline $\mathrm{AK} 1 \mathrm{BB}$ & Bruchenbrücken, Friedl & LBK II & 2 & 2 & 1 & 1 & 20 & 201 & 10 & 10 & 866 & 866 & 4,81 \\
\hline AK114 HAR 6 & Harheim, Frankfurt (20) & LBK II & 8 & 8 & 10 & 10 & 328 & 328 & 14 & 14 & 553 & 553 & 1,08 \\
\hline AK123 NES & Nieder-Eschbach, Frankfurt (16) & LBK II & 16 & 16 & 26 & 26 & 27 & 275 & 64 & 64 & 78719 & 78719 & 177,64 \\
\hline AK134 NM & Nieder-Mörlen, Bad Nauheim (7) & LBK II & 35 & 30 & 56 & 7 & 519 & 437 & 69 & 65 & 41314 & 41112 & 134,94 \\
\hline $\mathrm{AK} 175 \mathrm{OE} 1$ & Ober-Erlenbach, Bad Homb. (12) & LBK II & 17 & 13 & 36 & 31 & 366 & 313 & 33 & 32 & 4882 & 4776 & 16,80 \\
\hline $\mathrm{AK} 1 \mathrm{BB}$ & Bruchenbrücken, Friedberg (11) & LBK III-V & 9 & 9 & 88 & 88 & 2287 & 2287 & 76 & 76 & 6950 & 6950 & 3,08 \\
\hline AK27 RAU & Raunheim (25) & LBK III-V & 2 & 2 & 5 & 5 & 36 & 36 & 14 & 14 & 448 & 448 & 9,75 \\
\hline AK33 FEC 14 & Fechenheim, Frankfurt (21) & LBK III-V & 20 & 20 & 48 & 48 & 899 & 899 & 57 & 57 & 18074 & 18074 & 24,37 \\
\hline AK41 EBN & Niederhöchstadt, Eschborn (19) & LBK III-V & 1 & 1 & 1 & 1 & 2 & 32 & 42 & 42 & 13404 & 13404 & I \\
\hline AK49 NIGRÜ & Niedergründau, Gründau (23) & LBK III-V & 5 & 5 & 7 & 7 & 166 & 166 & 21 & 21 & 1031 & 1031 & 6,70 \\
\hline AK57 KLOK & Kloppenheim, Karben (13) & LBK III-V & 5 & 5 & 8 & 8 & 215 & 215 & 21 & 21 & 928 & 928 & 6,60 \\
\hline AK66 MB & Mittelbuchen, Hanau (22) & LBK III-V & 43 & 41 & 49 & 45 & 498 & 460 & 41 & 41 & 3469 & 3435 & 7,27 \\
\hline AK76 WINI & Windecken, Nidderau (14) & LBK III-V & 3 & 3 & 3 & 3 & 1 & 1 & 9 & 9 & 67 & 67 & 67,19 \\
\hline AK84 GH & Hailer, Gelnhausen (24) & LBK III-V & 2 & 2 & 3 & 3 & 47 & 47 & 31 & 31 & 5524 & 6524 & 66,41 \\
\hline AK85 MAR23 & Mardorf, Amöneburg (5) & LBK III-V & 2 & 2 & 2 & 2 & 10 & 10 & 7 & 7 & 36 & 36 & 3,60 \\
\hline AK99 US1 & Usingen (9) & LBK III-V & 19 & 16 & 85 & 52 & 1070 & 509 & 62 & 49 & 24985 & 10550 & 16,34 \\
\hline AK102 KRON & Kronberg/Taunus (18) & LBK III-V & 1 & 1 & 12 & 1 & 164 & 1 & 16 & I & 263 & I & $\gamma$ \\
\hline AK134 NM & Nieder-Mörlen, Bad Nauheim (7) & LBK III-V & 18 & 18 & 21 & 21 & 209 & 209 & 55 & 55 & 43852 & 43852 & 193,96 \\
\hline AK152 HERX & Herxheim/Landau (28) & LBK III-V & 9 & 7 & 81 & 10 & 689 & 26 & 66 & 19 & 5468 & 752 & 21,27 \\
\hline AK154 FAU & Fauerbach v. d. H., Butzbach (8) & LBK III-V & 35 & 32 & 46 & 43 & 515 & 457 & 68 & 68 & 17833 & 17101 & 24,56 \\
\hline AK168 WEM & Wembach-Hahn, Ober-Ram. (27) & LBK III-V & 1 & 1 & 3 & 3 & 30 & 30 & 22 & 22 & 1931 & 1931 & 64,37 \\
\hline AK176 WW & Wernswig, Homberg (Efze) (3) & LBK III-V & 5 & 3 & 12 & 10 & 115 & 97 & 30 & 30 & 1075 & 1017 & 9,71 \\
\hline AK194 BRA & Bracht, Rauschenberg (4) & LBK III-V & 5 & 4 & 6 & 4 & 107 & 88 & 22 & 22 & 1208 & 1199 & 18,65 \\
\hline total & & & 494 & 458 & 1627 & 1436 & 27210 & 24888 & 1 & 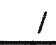 & 444783 & 423831 & \\
\hline
\end{tabular}



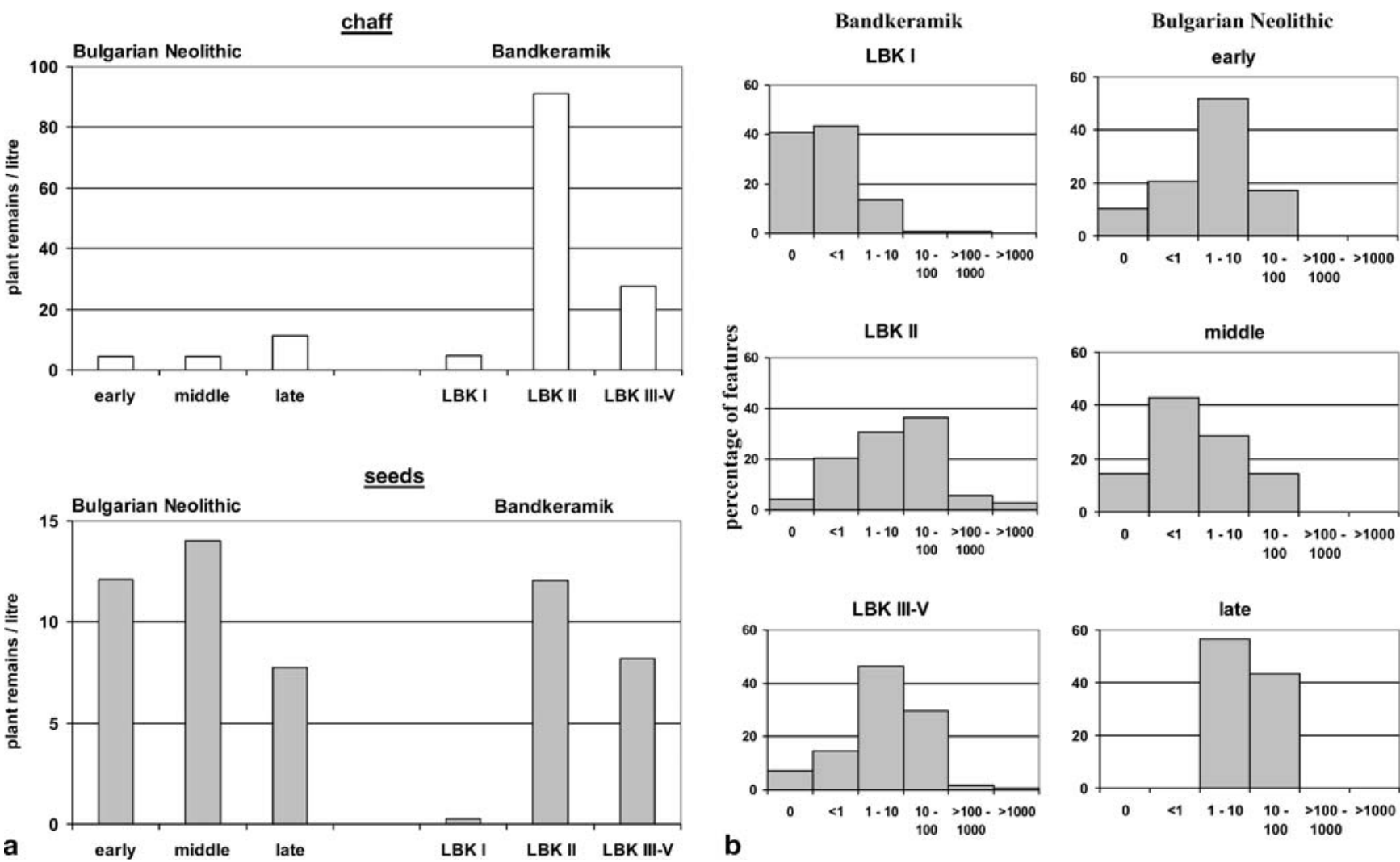

Fig. 3 a Average concentration of chaff and seeds per feature or context calculated for the Bulgarian Neolithic and for the Bandkeramik sites. b Percentage of features with different ranges of chaff concentrations (number of chaff remains per litre)

\section{Crop species}

We may assume that crops were a major component of early Neolithic nutrition in both cultures. Local production is expected for all sites investigated. Cultivated species occurring as solitary finds only are not interpreted as intentionally grown crops. At Bulgarian Neolithic sites these are Panicum miliaceum (broomcorn millet) and Coriandrum sativum (coriander) (Table 4, Fig. 13). At Bandkeramik sites these are Hordeum sp. (barley), $\mathrm{Pa}$ nicum miliaceum (broomcorn millet), Secale cereale (rye), Vicia ervilia (bitter vetch) and Vicia faba (Celtic bean) (Table 5, Fig. 13). These single finds are interpreted as weeds which were introduced in seedcorn. Nevertheless they are interesting for considerations concerning supra-regional contacts.

The range of cultivated crop species is different in the two cultures (Tables 4-6). The Bandkeramik assemblage comprises five crop species only: Triticum dicoccum (emmer) and T. monococcum (einkorn) (partly of a twoseeded form: Kreuz and Boenke 2002, for Bulgaria: Marinova 2001; see also Tables 4 and 5), Pisum sativum (pea) and Lens culinaris (lentil) as well as Linum usitatissimum (flax). At one earliest Bandkeramik site (AK184 Bad Camberg-Würges, unpubl.) and one Bulgarian Neolithic site (Karanovo 99/23) glume bases of the "new type" wheat have been found (Fig. 13; for identi- fication criteria, see Jones et al. 2000; Kohler-Schneider 2003).

There are some hints given by storage finds, that einkorn and emmer were sometimes grown as maslins (mixed crops) by Bandkeramik as well as Bulgarian Neolithic farmers, partly even together with pea (Kreuz in press a; Marinova 2001, p 98; for the general discussion of maslins see Jones and Halstead 1995). In addition, the Bandkeramik farmers maintained lentil and flax fields. Papaver somniferum (opium poppy) is not recorded before Bandkeramik phase II. It may point to direct or indirect contacts with the western Mediterranean (Bakels 1982; Kreuz 1993). Opium poppy is absent from all Balkan Neolithic sites.

The Neolithic crop assemblage of Bulgaria comprises two additional cereals: Hordeum sp. (barley) and Triticum aestivum s.l./durum/turgidum (naked wheat), as well as three additional pulses: Cicer arietinum (chickpea), Lathyrus sativus vel cicera (grass pea) and Vicia ervilia (bitter vetch) (Table 4, Fig. 13; Marinova 2001). All in all, these five more crop species grown by the farmers of the Bulgarian Neolithic imply a different agricultural system.

If we look at the countries adjacent to Bulgaria and outside the Linearbandkeramik area we can see that the two additional cereals, barley and naked wheat, were grown in the sphere of influence of all cultures belonging to the Starčevo-Körös-Čris complex including eastern 
Table 4 Archaeobotanical records of cultivated plants from six Neolithic sites in Bulgaria (see also Table 2 and Fig. 2)

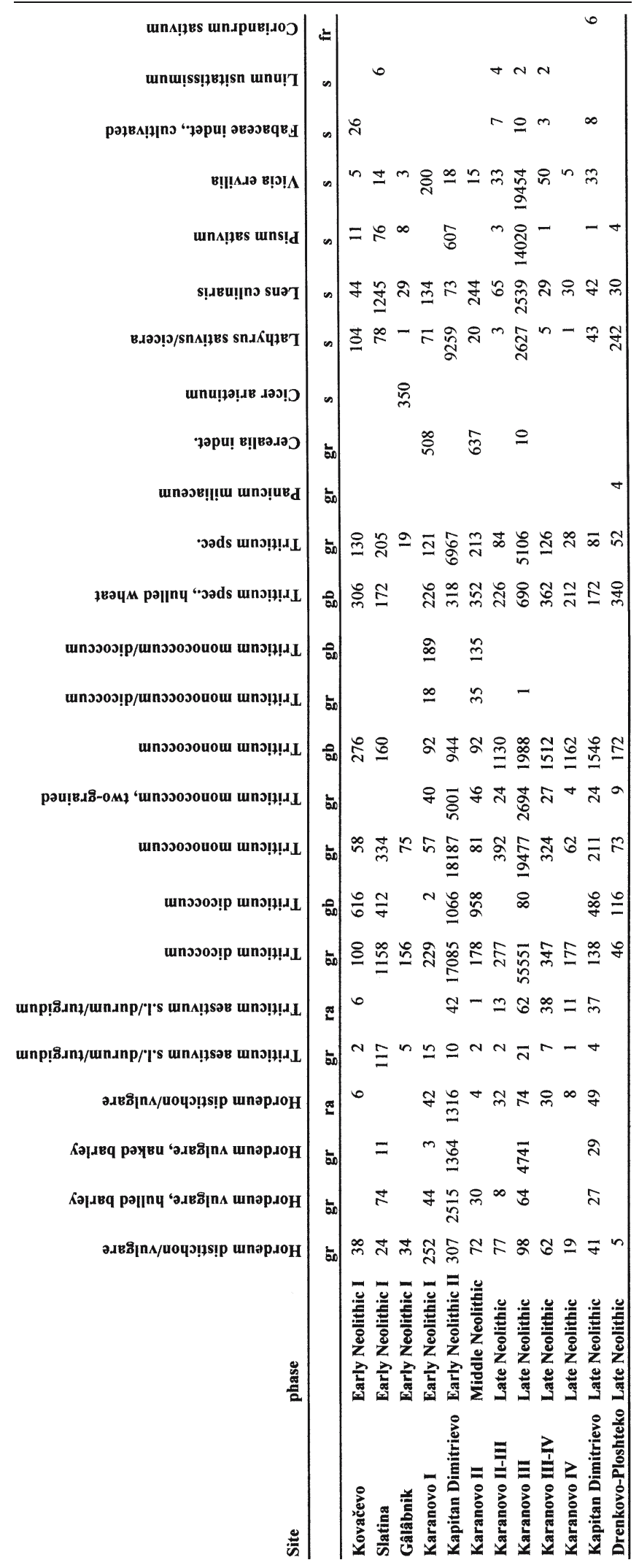

Hungary (Table 6 and Fig. 1). The pulses do not all reach eastern Hungary, but it is difficult to decide whether this is due to the state of research or to other reasons (data from Greece: Evi Margaritis unpublished data from the site Dispilio/Kastoria; Hubbard and Housley 2000; Valamoti 2004, Valamoti and Jones in press; Hungary: Amy Bogaard and Ferenc Gyulai unpublished data (see also Bogaard et al. in press); former Yugoslavia: F. Bittmann and D. Kučan unpublished data from Okoliste/ Visoko in Bosnia; Ksenija Borojevič, Dragana Filipovič from the Vinča site (Borojevič 1998; Borojevič and Filipovič in press); Van Zeist 2003; Romania: Cârciumaru 1995; Cârciumaru and Monah 1987; F. and D. Monah 1996; Turkish Thrace: Reinder Neef personal communication for the site Aşaği Pinar; general overviews: Hopf 1991; Kroll 1991; Wasylikowa et al. 1991).

The spectrum of Bandkeramik crop species is limited. Only some of the species cultivated in Neolithic Bulgaria finally reached the area of the Bandkeramik in Austria and Germany in early Neolithic times. This phenomenon has to be discussed further (see below).

\section{The relationship of einkorn and emmer}

Figure 4 presents the relative quantities of chaff remains from emmer and einkorn per settlement for those sites where both species were recorded. It is evident that at most sites more remains from einkorn than from emmer occur. This holds true for most Bandkeramik sites (see also Knörzer 1991, 1997 for the Rhineland area) and also for the contemporary late Neolithic Bulgarian sites (Fig. 4; see also for example Van Zeist 2003 for Gomolava and surrounding regions). If one looks at the same calculation based on grains (without figure) the result is not that clear. Nevertheless most sites of the second half of the Bandkeramik culture have higher values of einkorn too.

The results suggest that einkorn was the dominant Bandkeramik cereal. This is quite surprising, as einkorn would seem to be the worse choice. The yield of einkorn is almost half of that of emmer (Körber-Grohne 1988; Van der Veen 1997; organic farmers personal communication). In addition the lower tillering rate of einkorn allows more weeds to grow in the fields in relation to emmer (organic farmers personal communication). So why should anyone prefer einkorn? Einkorn is considered to be more winter hardy than emmer (Körber-Grohne 1988, pp 322ff.). But another characteristic seems even more important. Einkorn is the only cultivated cereal which, due to the characteristics of its straw, keeps standing after heavy rainfall (Fig. 10 in Kreuz in press a). Emmer on the other hand, as all other cereals, tends to lodge (personal communication of organic farmers and own observation). Lodging of cereal plants may reduce the yield seriously. In the event of frequently occurring heavy rainfall during the Atlantic period (see above) einkorn would have been the better choice (Kreuz in press a). Due to that possible climatic interpretation of einkorn 


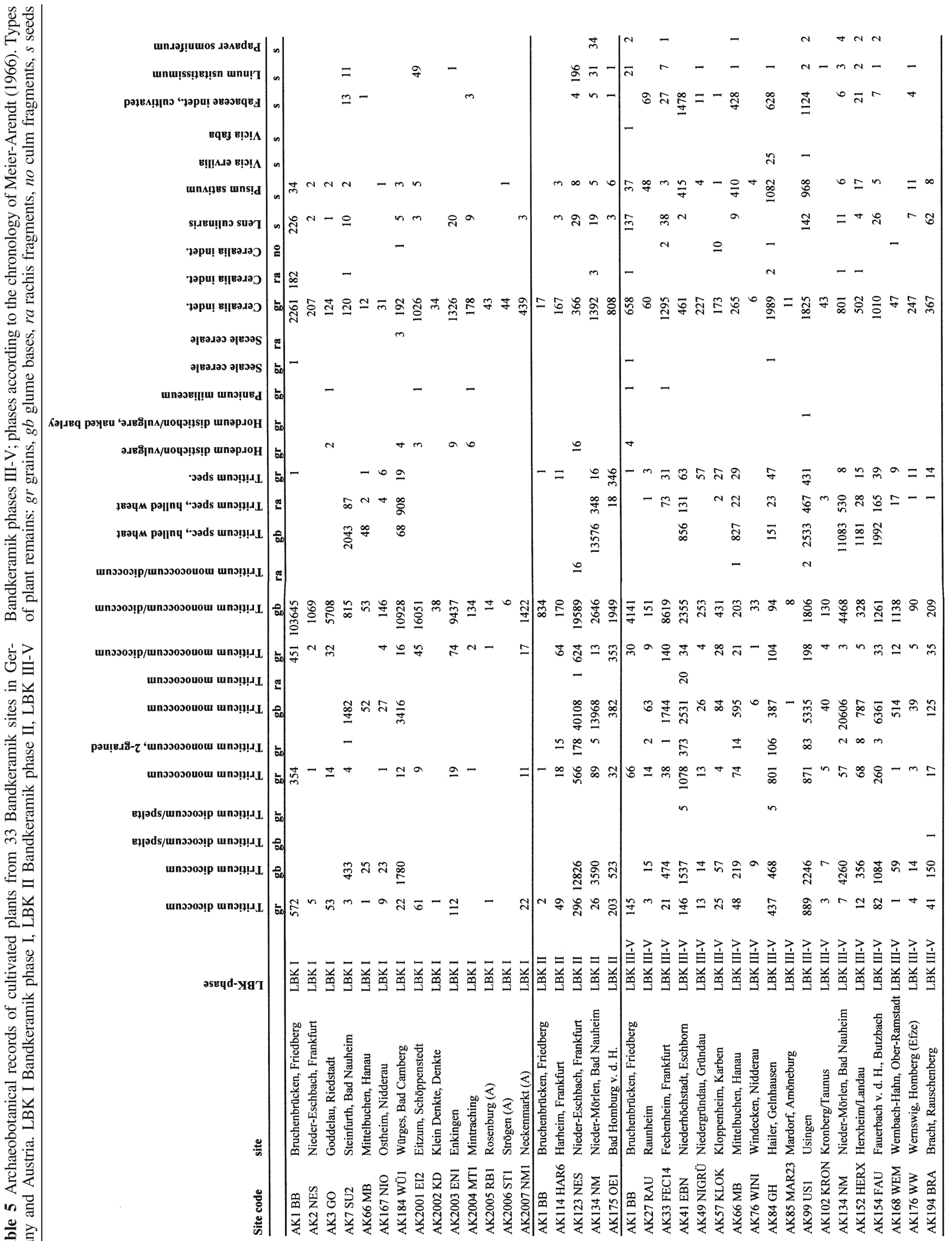


Table 6 Comparison of crop species in Neolithic Europe (for explanation and references see text)

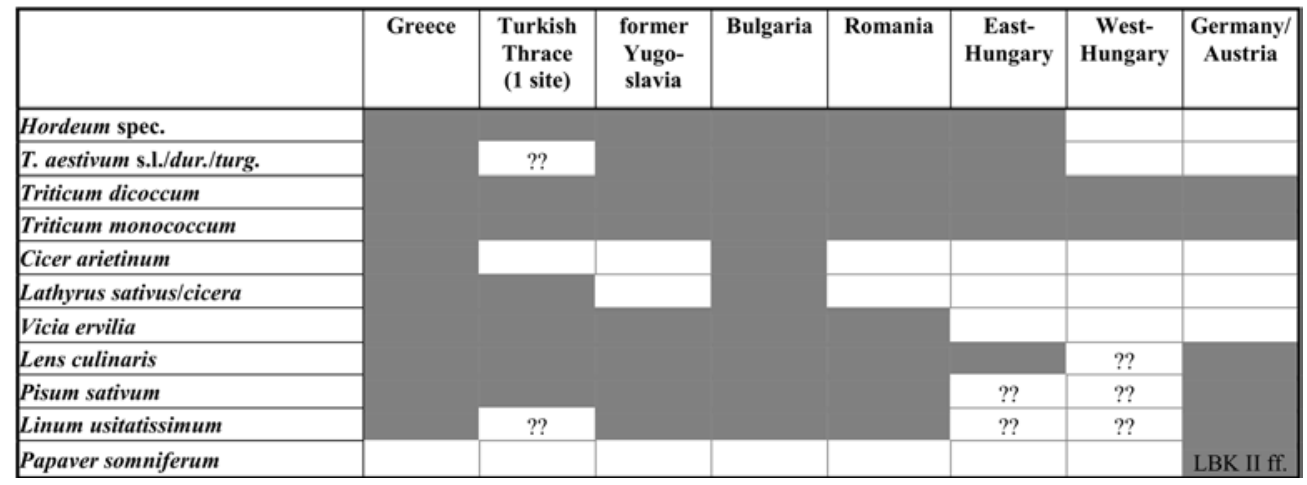

Bandkeramik

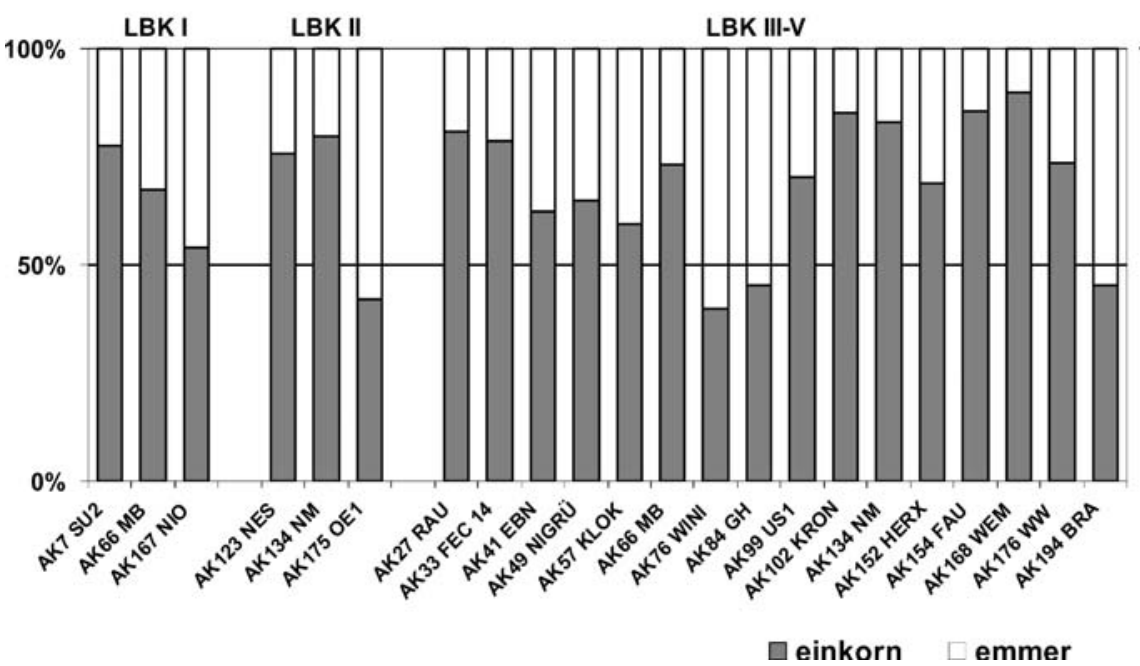

Bulgarian Neolithic

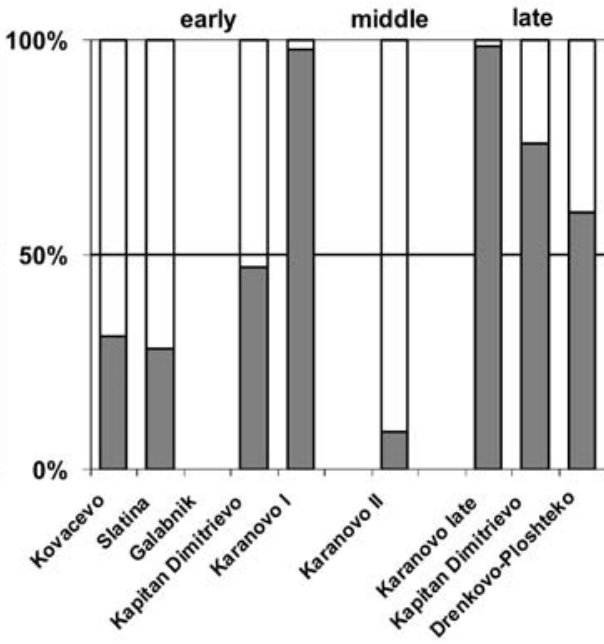

Fig. 4 Relative quantities of chaff remains from emmer and einkorn per settlement calculated for Bandkeramik and for Bulgarian Neolithic sites (for the abbreviations of the sites see Table 3, for the location of the sites see Fig. 2)

dominance it seems worthwhile to explore this question further.

\section{Potential weeds as indicators for agricultural practices}

Storage finds of crops with associated weeds are almost absent from Bandkeramik sites. In the data from both regions no relationship is evident between certain species and the different crops. How can we know if a taxon found in 'normal' samples was a weed or not? To answer this question we need chorological and ecological data for each potential weed species (Kreuz 1990, pp 143ff.).

The central European flora can be divided into two groups: there are plants which came into a region without anthropogenic influence and help. These are the indigenous species called idiochores (Idiochoren; for the terms see Schroeder 1969, 1974). Some of them are able to establish themselves as ruderals or weeds in the fields. Such potential weeds are called apophytes (Apophyten).

Secondly there are species which could only come to a region and persist by direct or indirect human influence.

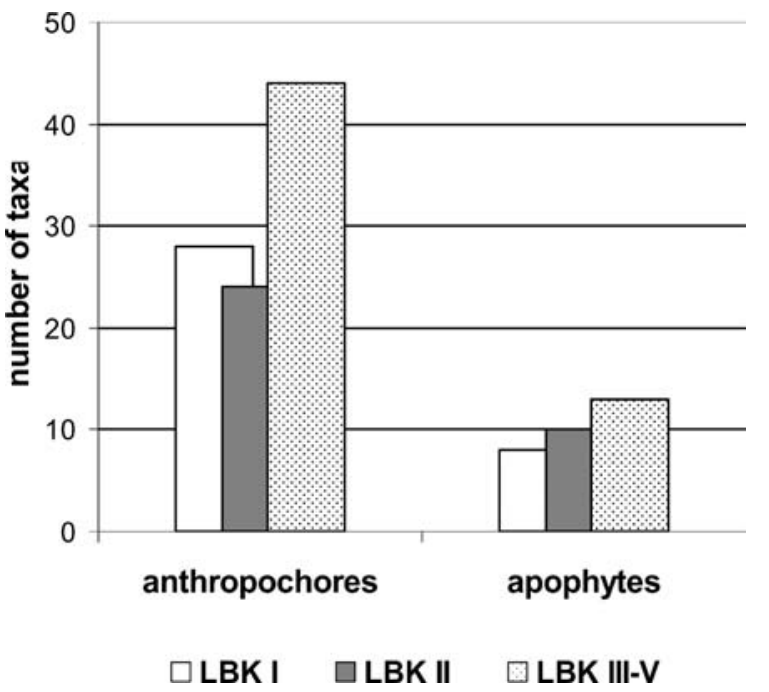

Fig. 5 Number of anthropochores and apophytes recorded from Bandkeramik phases I, II and III-V (see also Table 7) 
Table 7 Bandkeramik potential weed species and their characteristics (following Oberdorfer 1990, 2001 and Kästner et al. 2001) and numbers of plant remains. APO apophyte, $A N T$ anthropochore; height: low 0-40 cm, medium 50-80 cm, high $>80 \mathrm{~cm}$; life-form: $s$ summer-annual, $w$ winter-annual/biennial, per perennial, / indif- ferent; area: euras eurasiatic, including no-euras, euras-smed, euras(...); eurassubozean eurasiatic-suboceanic, including subatl subatlantic; kont kontinental; med et al. mediterranean, including med-smed, smed-med, med(...); smed submediterranean; omed eastern mediterranean, including eastern submediterranean

\begin{tabular}{|c|c|c|c|c|c|c|c|}
\hline Botanical name & APO/ANT & height & life-form & area & LBK I & LBK II & LBK III-V \\
\hline Agrostis stolonifera/capillaris & ANT & medium & per & 1 & & & 7 \\
\hline Asperula arvensis & ANT & low & / & med et al. & & & 1 \\
\hline Atriplex patula/hastata & ANT & medium & s & euras-(s)med & 1 & 4 & 10 \\
\hline Atropa bella-donna & APO & high & per & eurassubozean-smed & & 4 & \\
\hline Avena spec. & ANT & high & $\mathrm{s}$ & med et al. & & & 2 \\
\hline Avena/Bromus & ANT & high & l & / & & & 1 \\
\hline Brassica spec. & ANT & high & l & med et al. & & & 7 \\
\hline Bromus cf. arvensis & ANT & medium & l & euras-(s)med & & 31 & 112 \\
\hline Bromus cf. secalinus & ANT & medium & l & euras & 158 & 405 & 1671 \\
\hline Bromus spec. & l & medium & / & 1 & 35 & 188 & 4850 \\
\hline Bromus sterilis & ANT & low & l & med et al. & & 128 & 249 \\
\hline Bromus sterilis/tectorum & ANT & low & / & med et al. & & 57 & 343 \\
\hline Bupleurum falcatum s.str. & APO & medium & per & kont & & & 1 \\
\hline Calystegia sepium & APO & high & s & eurassubozean-smed & & & 2 \\
\hline Capsella bursa-pastoris & ANT & low & s & med et al. & & & 3 \\
\hline Carex muricata agg. & $\mathrm{APO}$ & medium & per & eurassubozean & & 2 & \\
\hline Centaurea spec. & ANT & 1 & I & 1 & 1 & & 1 \\
\hline Cerastium spec. & 1 & low & per & / & & & 1 \\
\hline Chenopodium album & ANT & high & s & euras-(s)med & 960 & 4903 & 9544 \\
\hline Chenopodium hybridum & ANT & medium & $\mathrm{s}$ & euras & 2 & 2 & 4 \\
\hline Digitaria sanguinalis & ANT & low & $\mathrm{s}$ & med et al. & & & 1 \\
\hline Echinochloa crus-galli & ANT & medium & s & euras-(s)med & 2 & 51 & 50 \\
\hline Echinochloa/Setaria & ANT & medium & s & med et al. & & & 1 \\
\hline Eleocharis palustris agg. & $\mathrm{APO}$ & medium & per & euras & 1 & & \\
\hline Euphrasia/Odontites & ANT & low & s & 1 & & & 2 \\
\hline Festuca/Lolium & ANT & l & l & 1 & & & 6 \\
\hline Fragaria vesca & $\mathrm{APO}$ & low & per & euras & & 4 & 12 \\
\hline Galium aparine/spurium & ANT & high & $\mathrm{s}$ & euras & 5 & 5 & 211 \\
\hline Galium cf. aparine & ANT & high & $\mathrm{s}$ & euras & 14 & 31 & 152 \\
\hline Galium cf. verum agg. & ANT & medium & per & euras-(s)med & & 132 & 190 \\
\hline Galium mollugo/verum & / & high & per & med et al. & & & 7 \\
\hline Galium palustre & APO & low & per & eurassubozean & 2 & & \\
\hline Galium spurium & ANT & high & s & euras-(s)med & 17 & 113 & 1398 \\
\hline Hordeum spec. & ANT & high & 1 & med et al. & & 1 & \\
\hline Hyoscyamus niger & ANT & medium & $\mathrm{s} ?$ & euras-(s)med & & & 2 \\
\hline Knautia arvensis & ANT & medium & per & eurassubozean & & 1 & \\
\hline Lapsana communis & $\mathrm{APO}$ & high & $\mathrm{w}$ & eurassubozean-smed & 1 & 173 & 576 \\
\hline Lolium spec. & ANT & medium & / & med et al. & & & 17 \\
\hline Lotus corniculatus s.str. & ANT & low & per & eurassubozean-smed & & & 1 \\
\hline Lotus uliginosus & $\mathrm{APO}$ & medium & per & eurassubozean-smed & & 1 & \\
\hline Malva spec. & ANT & 1 & i & 1 & & 4 & 11 \\
\hline Malva sylvestris & ANT & high & per & euras-(s)med & & 2 & \\
\hline Matricaria perforata & ANT & medium & s & kont & 1 & & \\
\hline Medicago lupulina & ANT & low & I & euras-(s)med & & & 1 \\
\hline Myosoton/Stellaria & l & low & / & euras & & & 1 \\
\hline Nepeta cf. cataria & ANT & high & per & kont & 13 & & 9 \\
\hline Papaver dubium/rhoeas & ANT & medium & / & med et al. & & & 1 \\
\hline Phleum pratense s.l. & ANT & high & per & euras & 356 & 1872 & 1784 \\
\hline Phleum pratense/Poa annua & ANT & 1 & 1 & euras & 1 & 15 & 7 \\
\hline Picris hieracioides s.l. & ANT & medium & per & euras-(s)med & 1 & 1 & \\
\hline Plantago lanceolata & / & low & per & eurassubozean & & & 2 \\
\hline Plantago major s.str. & APO & low & per & eurassubozean & & & 1 \\
\hline Plantago major ssp. intermedia & $\mathrm{APO}$ & low & s? & eurassubozean & & & 2 \\
\hline Poa annua & ANT & low & / & euras-(s)med & 9 & 5 & 6 \\
\hline Poa spec. non annua & / & 1 & per & 1 & & 2 & 11 \\
\hline
\end{tabular}


Table 7 continued

\begin{tabular}{|c|c|c|c|c|c|c|c|}
\hline Botanical name & APO/ANT & height & life-form & area & LBK I & LBK II & LBK III-V \\
\hline Poaceae Bromus/Festuca type & ANT & 1 & 1 & / & & 13 & 10 \\
\hline Polygonum aviculare agg. & ANT & medium & $\mathrm{s}$ & euras-(s)med & 2 & 5 & 14 \\
\hline Polygonum convolvulus & ANT & medium & $\mathrm{s}$ & euras & 410 & 728 & 945 \\
\hline Polygonum dumetorum & $\mathrm{APO}$ & high & $\mathrm{s}$ & euras-(s)med & 70 & 16 & 6 \\
\hline Polygonum convolvulus/aviculare & ANT & medium & $\mathrm{s}$ & euras & 6 & 44 & 395 \\
\hline Polygonum convolvulus/dumetorum & l & / & $\mathrm{s}$ & euras & & 7 & 12 \\
\hline Polygonum hydropiper/mite & / & medium & $\mathrm{s}$ & / & & 1 & 1 \\
\hline Polygonum lapathifolium agg. & $\mathrm{APO}$ & medium & $\mathrm{s}$ & eurassubozean & 9 & 40 & 17 \\
\hline Polygonum lapathifolium/persicaria & / & medium & $\mathrm{s}$ & / & 2 & 3 & 16 \\
\hline Polygonum persicaria & ANT & medium & $\mathrm{s}$ & euras & & & 3 \\
\hline Rhinanthus cf. minor & ANT & low & $\mathrm{s}$ & eurassubozean & & & 2 \\
\hline Rumex acetosella agg. & ANT & low & per & euras & 3 & & 1 \\
\hline Rumex conglomeratus/sanguineus & $\mathrm{APO}$ & medium & per & med et al. & & 34 & 3 \\
\hline Rumex crispus/obtusifolius & $\mathrm{APO}$ & high & per & / & 1 & & 37 \\
\hline Sambucus ebulus & $\mathrm{APO}$ & high & per & med et al. & 3 & & 3 \\
\hline Scirpus spec. & $\mathrm{APO}$ & / & l & 1 & & & 5 \\
\hline Scleranthus annuus s.str. & ANT & low & $\mathrm{s} ?$ & eurassubozean-smed & 1 & & 3 \\
\hline Setaria verticillata/viridis & ANT & medium & $\mathrm{s}$ & euras-(s)med & 9 & 13 & 138 \\
\hline Sherardia arvensis & ANT & low & s? & med et al. & & & 1 \\
\hline Sinapis arvensis & ANT & medium & s & med et al. & 1 & & \\
\hline Sisymbrium spec. & ANT & / & $\mathrm{s} ?$ & 1 & & 4 & \\
\hline Solanum nigrum & ANT & medium & $\mathrm{s}$ & euras-(s)med & 3 & 124 & 194 \\
\hline Solanum spec. & / & / & l & euras-(s)med & 3 & 3 & 11 \\
\hline Stachys arvensis & ANT & low & $\mathrm{s}$ & eurassubozean & & & 1 \\
\hline Stellaria graminea & ANT & low & per & eurassubozean & 1 & & 12 \\
\hline Stellaria media agg. & ANT & low & I & euras-(s)med & 1 & 2 & \\
\hline Stipa spec. & ANT & medium & per & kont & 11 & & \\
\hline Thlaspi arvense & ANT & low & l & euras-(s)med & 1 & & 1 \\
\hline Torilis arvensis/japonica & / & high & I & med et al. & & & 1 \\
\hline Trifolium campestre/dubium & ANT & low & s? & eurassubozean-smed & & & 2 \\
\hline Trifolium campestre/dubium/arvense & ANT & low & s? & eurassubozean-smed & 4 & 2 & 14 \\
\hline Trifolium medium/pratense & $\mathrm{APO}$ & low & per & eurassubozean-smed & & 1 & \\
\hline Trifolium spec. & l & low & l & 1 & & 1 & 5 \\
\hline Urtica dioica & $\mathrm{APO}$ & high & per & euras & 1 & 2 & 3 \\
\hline Valerianella dentata & ANT & low & w & med et al. & & & 4 \\
\hline Valerianella locusta & ANT & low & w & med et al. & & & 1 \\
\hline Verbascum spec. & l & high & per & 1 & & & 4 \\
\hline Veronica arvensis & ANT & low & i & eurassubozean-smed & 1 & & 79 \\
\hline Vicia hirsuta & ANT & medium & $\mathrm{s} ?$ & euras-(s)med & & 2 & 9 \\
\hline Vicia tetrasperma & ANT & medium & s? & eurassubozean-smed & 1 & & \\
\hline Vicia hirsuta/tetrasperma & ANT & medium & s? & 1 & 4 & 1 & 57 \\
\hline Viola spec. & 1 & low & l & 1 & & & 1 \\
\hline
\end{tabular}

These species, which do not grow in natural stands, are called anthropochores according to their method of dispersal (Anthropochoren). We can expect that all anthropochores of the Neolithic were brought in with seeds or by other means during the colonization of the landscapes. That is why they might represent weeds. In addition in the Neolithic they almost certainly indicate a movement of people (see below).

Based on Oberdorfer (1990, 2001) we grouped all species found at Bandkeramik sites into apophytes and anthropochores. All in all 64 anthropochores and 19 apophytes were identified (Table 7). For the Bulgarian area we have not yet found satisfactory information on this subject.

In Fig. 5 the number of anthropochores and apophytes is presented for the Bandkeramik phases. It is evident that most species are anthropochores, which were brought in from elsewhere. Apophytes from the natural vegetation form only a minor part of the spectra. In addition it is interesting that in phases III-V significantly more anthropochores have been found. If we look at the single sites, this is also the case: many more species per site are found from phase II onwards (Fig. 6).

Among the apophytes there are no real woodland species. This is probably due to the fact that woodland 


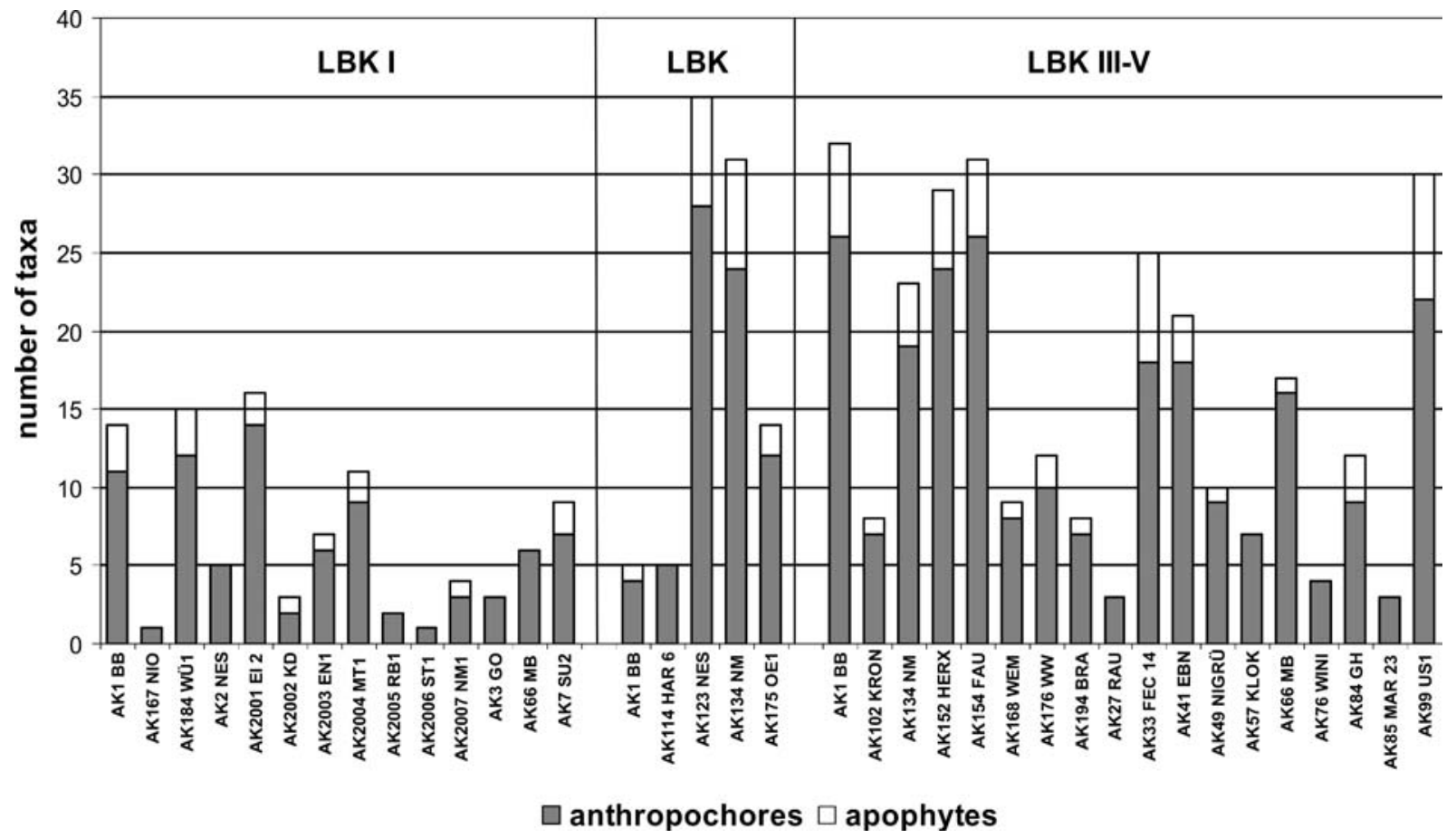

Fig. 6 Number of anthropochores and apophytes recorded per site for the Bandkeramik phases I, II and III-V (for the site codes see Table 3, for the location of the sites see Fig. 2)

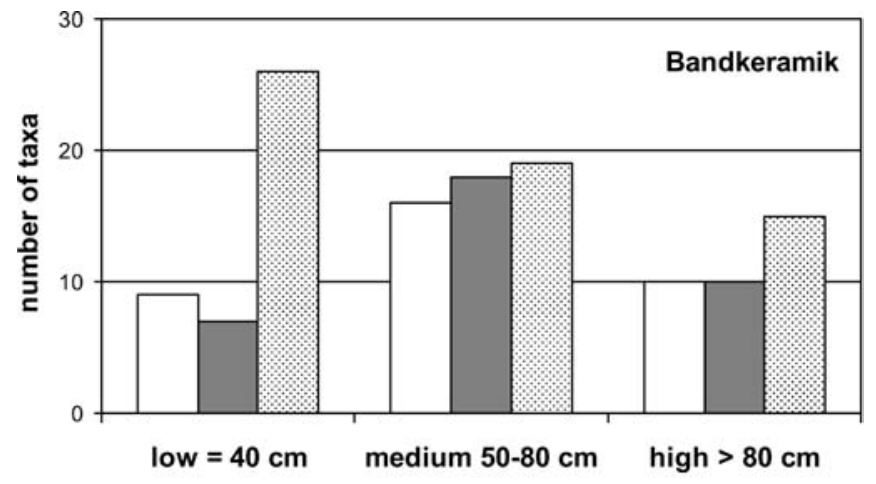

$\square$ LBK I $\square$ LBK II $\square$ LBK III-V

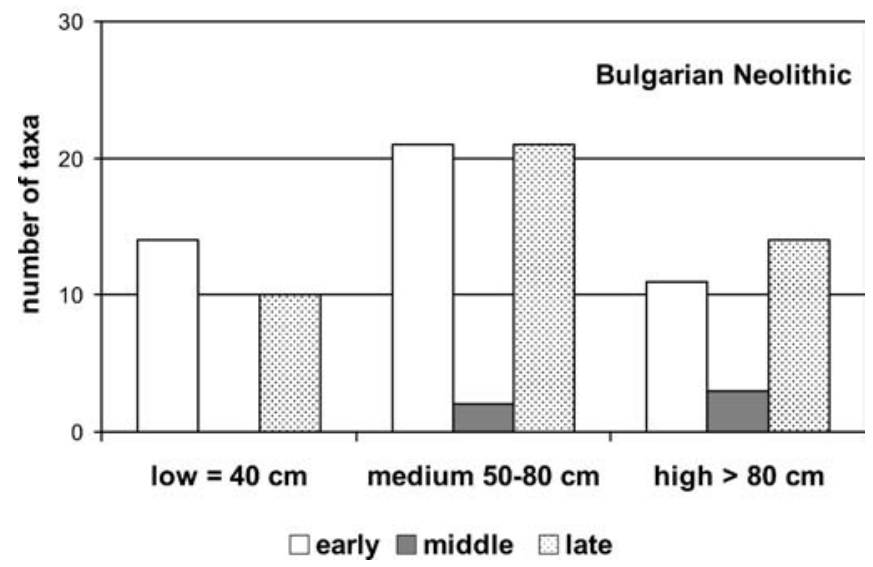

Fig. 7 Number of potential weed taxa of different growth height for the Bandkeramik and for the Bulgarian Neolithic phases (see also Tables 7 and 8) species are not adapted to grow as weeds under the "steppe-like" (Van Zeist 1987) and regularly disturbed conditions of a field (shrubs and trees are excluded from the data set presented here). On the contrary, almost all Bandkeramik apophytes today normally grow in the floodplains of river valleys. Possibly they were brought to the fields with the dung of cattle which grazed the floodplains as well as the harvested fields.

Figure 7 shows the growth height of the potential weeds compared for the Bulgarian Neolithic and the Bandkeramik cultures. Looking at the Bulgarian data, no chronological variation can be detected. It has to be mentioned that the only middle Neolithic site revealed very few species. That is why the apparent decrease of taxa there is an 'artefact'.

On the contrary, the Bandkeramik data show a chronological development (see also Fig. 8 for the single sites). As mentioned before, there are some more weeds in the later Bandkeramik phases III-V. It is evident that many of these newcomers are low-growing plants of about $40 \mathrm{~cm}$ maximum height (Figs. 7 and 8).

Possibly we have recorded here a change in the harvesting technique (Kreuz in press a). Following Hillman (1981) and Reynolds (1985, 1993, p 189), many more and also lower- as well as medium-growing weed plants and their seeds are collected by sickle- than by ear-harvesting. There is archaeological evidence that such a change in harvest technique took place. Flint working techniques and the quantities of lithic artefacts changed markedly between Bandkeramik phase I and the following phases: in earliest Bandkeramik settlements the percentage of 


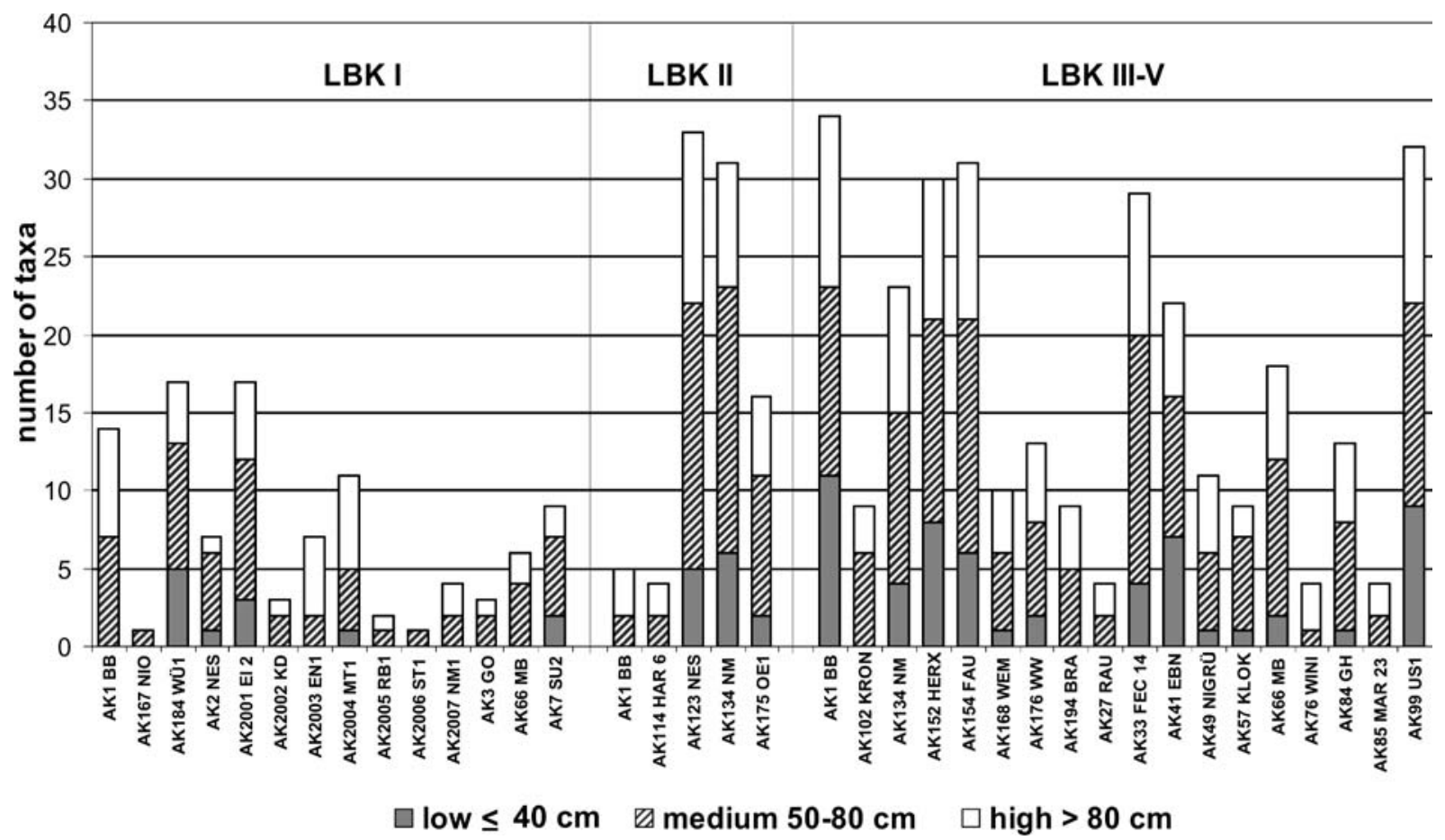

Fig. 8 Number of potential weed taxa of different growth height per site for the Bandkeramik phases I, II and III-V (for the site codes see Table 3, for the location of the sites see Fig. 2)

sickle blades is lower and less standardized (de Grooth 2003, p 402; Gronenborn 1997, p 102 and pers. comm.; Kind 1997, p 140). Possibly, sickles were less in use for harvest during Bandkeramik phase I than in the later Bandkeramik phases.

In contrast many fewer low growing species were found at the contemporary late Bulgarian Neolithic sites (Fig. 7). That is why we cannot exclude the possibility that ear harvesting remained important to the Bulgarian Neolithic farmers. Ear-plucking is an efficient method for harvesting the hulled wheats when fully ripe, as it prevents more ears from falling to the ground. It is for example written in the Bible that ear-plucking was practised by the disciples of Jesus (the gospel according to St. Mark, mk.02, 23-28).

On the other hand, experimental harvesting has revealed that harvesting with flint sickles is three times faster than ear-plucking (L. Peña-Chocarro, Como (I), and L. Zapata-Peña, Vittoria-Gasteiz (E) personal communication, see also Ibánez et al. 2001). The point in question is whether the use of this technological innovation was of different importance to the Bandkeramik compared with the Bulgarian Neolithic farmers.

There exist different opinions concerning the intensity of field management and the time of sowing during the Neolithic; their discussion goes beyond the scope of this paper (Bogaard 2004, chapter 7; Bakels and Rousselle 1985, p 55; Behre and Jacomet 1991, p 86; Willerding 1980; Lüning 2000). Important information derives again from the characteristics of the potential weeds.
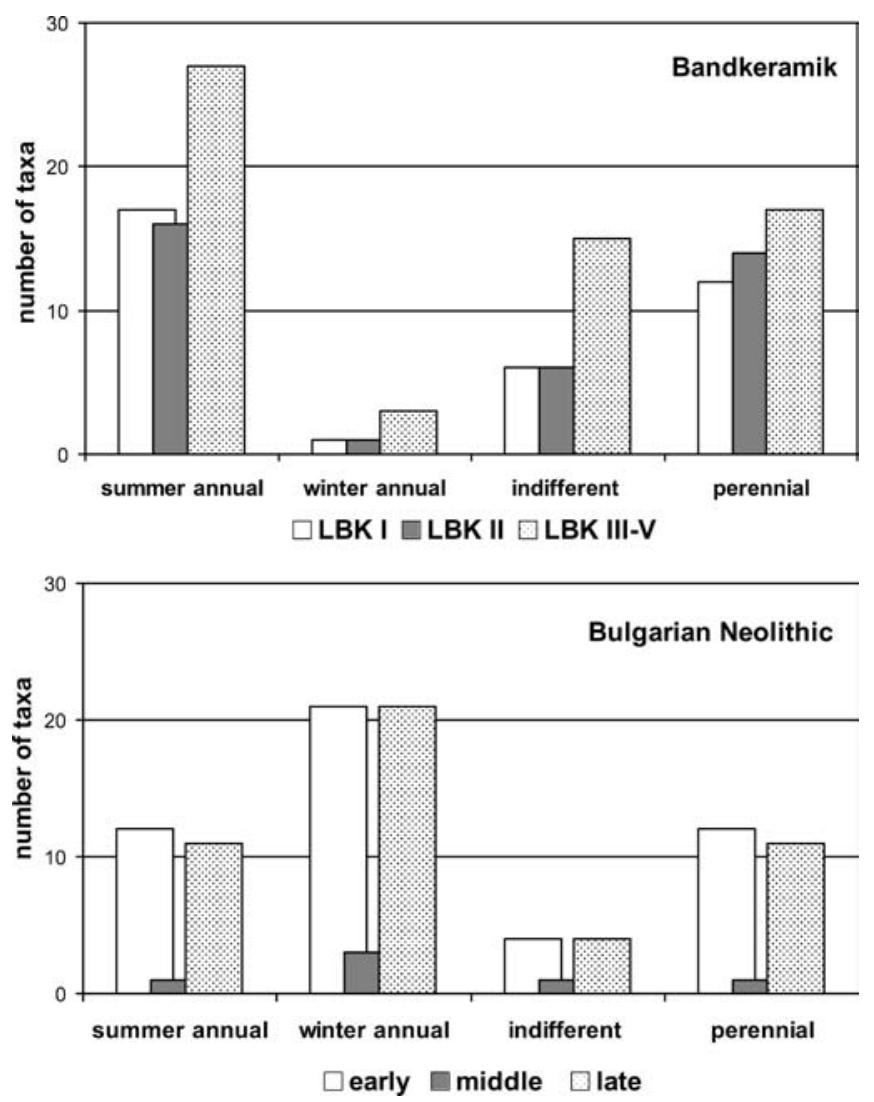

Fig. 9 Number of potential weed taxa of different life forms for the Bandkeramik and for the Bulgarian Neolithic phases (see also Tables 7 and 8) 


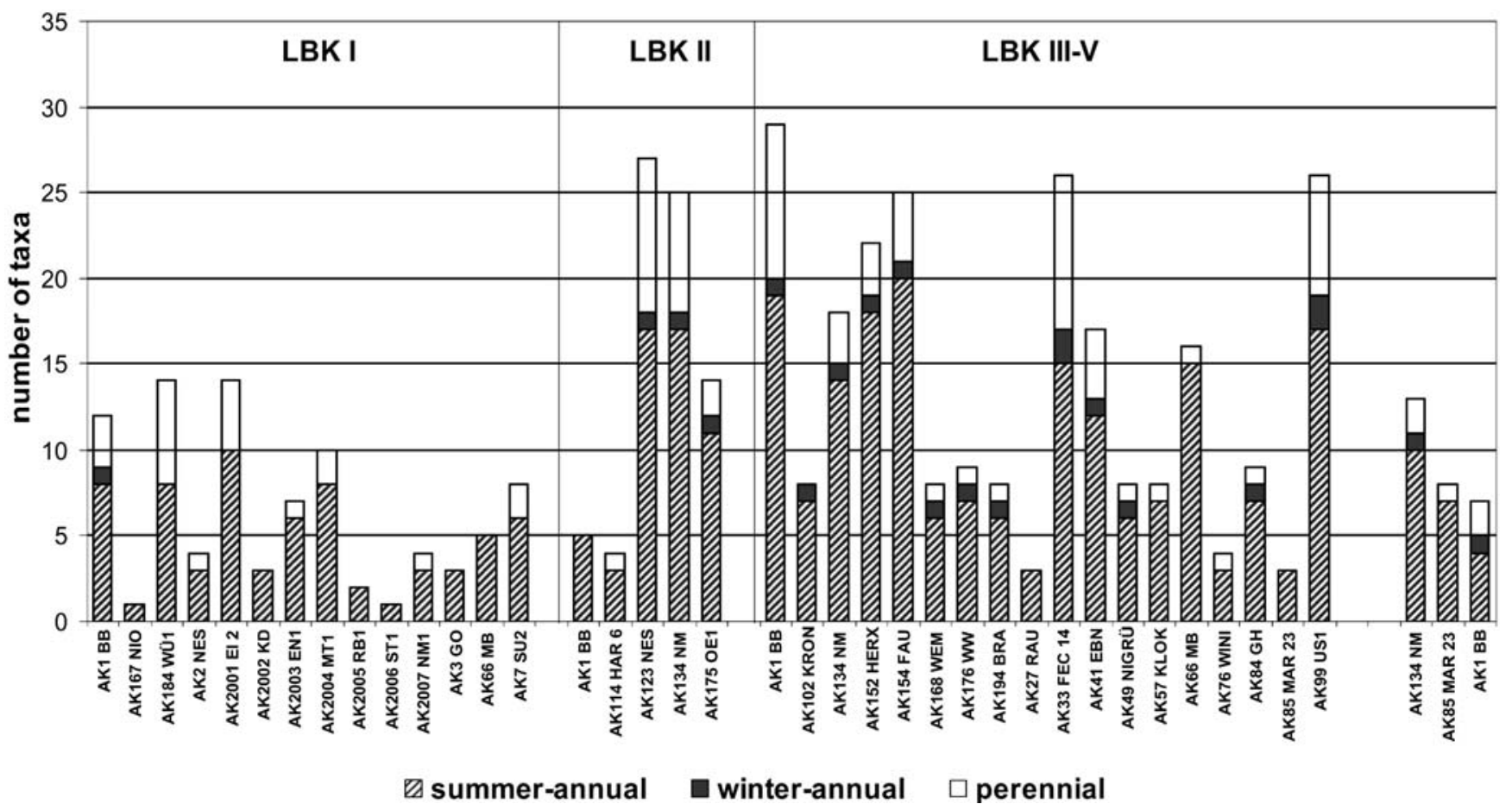

Fig. 10 Number of potential weed taxa of different life forms per site for the Bandkeramik phases (for the site codes see Table 3, for the location of the sites see Fig. 2). Indifferent taxa are excluded here, for clarity

The recorded potential weed species can be differentiated into four groups: summer annuals, winter annuals or biennials, indifferent species and perennials (after Oberdorfer 1990; Kästner et al. 2001). Figures 9 and 10 show again an important difference between the Bulgarian Neolithic and the Bandkeramik cultivation systems. At the Bulgarian sites the winter annual species are the dominant group, while summer annuals occur too. We may expect summer and winter crop growing there. At the Bandkeramik sites there are not more than three winter annuals but predominantly summer annuals. Figure 10 shows their occurrence per site. The only one of the three winter annuals occurring regularly is Lapsana communis. This is an apophyte and a common weed of diverse, especially ruderal, vegetation stands. It is not characteristic of winter crop cultivation. The other two species are Valerianella dentata (AK99 USI) and V. locusta (AK33 FEC) both occurring just as single finds in features of Bandkeramik phases III-V (Table 7). Therefore it seems to be likely that nothing but summer crop cultivation was practised by the Bandkeramik farmers.

In both cultures, perennials form an essential part of the weed assemblage. Therefore we should ask whether at least parts of the fields were not cultivated intensively. Characteristics of vegetative propagation and dispersal of the species concerned indicate whether they are able to reproduce, for example from their rhizomes or runners. Such species could possibly survive under intensive soil treatment by hoeing or similar activities. Actually, some of the Bandkeramik perennial species as for example Agrostis capillaris/stolonifera, Carex muricata, Galium

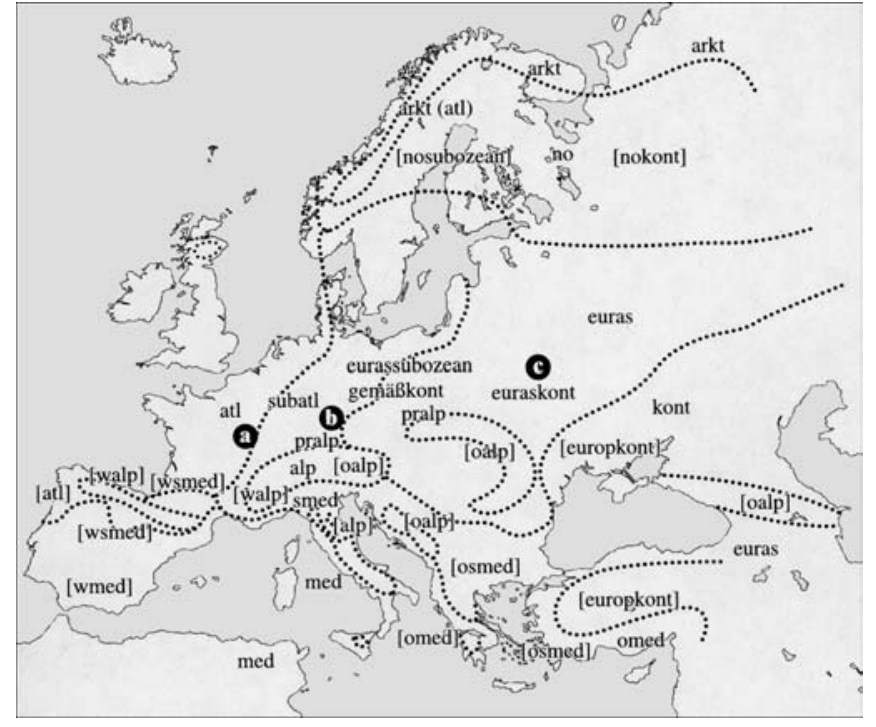

Fig. 11 Chorological areas of central Europe and adjacent areas (after Oberdorfer 2001). For abbreviations see Fig. 12 and Table 7

verum, Lotus uliginosus or Plantago lanceolata are able to propagate vegetatively, but others are not. To decide whether their occurrence in the samples really is a sign of the intensity of field management (Bogaard 2004; Jones et al. 1999), further research is needed. 
Table 8 Bulgarian Neolithic potential weed species and their characteristics and numbers of plant remains (for explanations see Table 7)

\begin{tabular}{|c|c|c|c|c|c|c|c|}
\hline Botanical name & height & $\begin{array}{l}\text { life- } \\
\text { form }\end{array}$ & area & $\begin{array}{c}\text { Early } \\
\text { Neolithic I } \\
\end{array}$ & $\begin{array}{c}\text { Early } \\
\text { Neolithic II } \\
\end{array}$ & $\begin{array}{c}\text { Middle } \\
\text { Neolithic } \\
\end{array}$ & $\begin{array}{c}\text { Late } \\
\text { Neolithic } \\
\end{array}$ \\
\hline Adonis flammea/A. aestivalis & medium & I & (o)(s)med & & 6 & & 4 \\
\hline Agrimonia eupatoria & low? & per & eurassubozean-smed & & 3 & & 6 \\
\hline Ajuga chamaepitys & low & s & med et al. & & 23 & & 13 \\
\hline Ajuga genevensis & low & per & euras-(s)med & & 4 & & \\
\hline Anagallis arvensis & low & w & eurassubozean-smed & 3 & 1 & & 2 \\
\hline Aphanes arvensis & low & 1 & med et al. & 5 & & & \\
\hline Asperula arvensis & medium & w & med et al. & 8 & 12 & & 19 \\
\hline Bromus ef. arvensis & high & w & euras-(s)med & 15 & 10 & & 21 \\
\hline Bromus sterilis & medium & w & med et al. & 1 & 4 & & 11 \\
\hline Bromus sterilis/tectorum & high & w & 1 & 4 & 25 & & 181 \\
\hline Chenopodium album & high & $\mathbf{s}$ & euras-(s)med & 129 & 150 & 50 & 500 \\
\hline Chenopodium hybridum & medium & $\mathbf{w}$ & euras & & & 12 & \\
\hline Chenopodium polyspermum & medium & w & eurassubozean-smed & 42 & 33 & & 81 \\
\hline Chenopodium ficifolium & medium & w & med et al. & 36 & 12 & & 26 \\
\hline Cirsium cf. arvense & high & per & euras-(s)med & & & & 11 \\
\hline Cirsium cf. vulgare & high & per & eurassubozean-smed & & 1 & & \\
\hline Convolvulus arvensis & high & per & euras-(s)med & & & & 4 \\
\hline Coriandrum sativum & medium & $\mathbf{s}$ & (o)(s)med & & & & 6 \\
\hline Coronilla cf. scorpioides & high & per & I & & & & 6 \\
\hline Echinochloa crus-galli & high & $\mathbf{s}$ & euras-(s)med & 6 & 11 & & 12 \\
\hline Festuca/Lolium & I & I & l & 12 & 11 & 5 & 5 \\
\hline Fragaria vesca & low & per & euras & 38 & 14 & & 13 \\
\hline Fumaria spec. & low & $\mathbf{w}$ & 1 & 5 & 8 & & 34 \\
\hline Galega officinalis & I & per & (o)(s)med & 6 & & & \\
\hline Galium cf. aparine & high & w & euras & 8 & 88 & 23 & 78 \\
\hline G.mollugo/G. album/G. heldreihii & medium & per & 1 & 2 & 35 & & 29 \\
\hline Galium cf. spurium & high & w & euras-(s)med & 30 & 69 & & 59 \\
\hline Heliotropium cf. europaeum & medium & $\mathbf{s}$ & (o)(s)med & & 16 & & 34 \\
\hline Hyoscyamus niger & medium & w & euras-(s)med & 2 & 3 & & 61 \\
\hline Lapsana communis & high & w & eurassubozean-smed & 2 & 4 & & 4 \\
\hline Lithospermum arvense & medium & w & $(o)(s) m e d$ & 33 & 12 & & 21 \\
\hline Phleum cf. phleoides & medium & $\mathbf{s}$ & euras & 8 & 4 & & 11 \\
\hline Physalis alkekengi & medium & per & euras-(s)med & 4 & 1 & & 5 \\
\hline Plantago cf. lanceolata & medium & per & eurassubozean & & 2 & & 9 \\
\hline Poa annua & low & w & euras-(s)med & & & & 5 \\
\hline Polycnemum arvense & low & $\mathbf{s}$ & (o)(s)med & 8 & 93 & & 49 \\
\hline Polygonum aviculare & medium & w & euras-(s)med & 45 & 42 & & 35 \\
\hline Polygonum convolvolus & medium & w & euras & 106 & 337 & 13 & 420 \\
\hline Portulaca oleracea & low & $\mathrm{s}$ & (o)(s)med & 89 & 10 & & 3 \\
\hline Rumex cf. acetosella agg. & medium & per & euras & & 6 & & \\
\hline Sambucus ebulus & high & per & med et al. & 5 & 15 & 15 & 55 \\
\hline Scirpus lacustris & high & per & euras-(s)med & & & & 9 \\
\hline Scleranthus cf. annuus & low & $\mathbf{w}$ & eurassubozean-smed & 4 & & & \\
\hline Setaria cf. pumila & medium & $\mathbf{s}$ & med et al. & 3 & 10 & & 10 \\
\hline Setaria viridis/verticillata & medium & $\mathbf{s}$ & euras-(s)med & 85 & 227 & & 214 \\
\hline Sherardia arvensis & low & $\mathbf{s}$ & med et al. & 7 & 9 & & \\
\hline Silene alba & medium & w & euras-(s)med & 5 & & & 1 \\
\hline Solanum nigrum & high & s & euras-(s)med & & 10 & & 10 \\
\hline Teucrium chamaedrys & low & per & med et al. & 11 & 239 & & 30 \\
\hline Thymelaea passerina & medium & w & med et al. & 3 & 22 & & 39 \\
\hline Trifolium cf. aureum & low & $\mathrm{s}$ & kont & 4 & 4 & & 0 \\
\hline Trifolium cf. campestre/repens & medium & per & eurassubozean-smed & 17 & 27 & & \\
\hline Trigonella /Astragalus & medium & I & I & & & & 4 \\
\hline Valerianella dentata & low & w & med et al. & 8 & 8 & & 42 \\
\hline Verbena officinalis & 1 & I & eurassubozean-smed & 4 & 1 & & 5 \\
\hline Vicia tetrasperma/hirsuta & medium & $\mathrm{w}$ & ' & 15 & 244 & & 43 \\
\hline Vicia villosa/angustifolia & high & w? & (o)(s)med & & 2 & & 3 \\
\hline
\end{tabular}



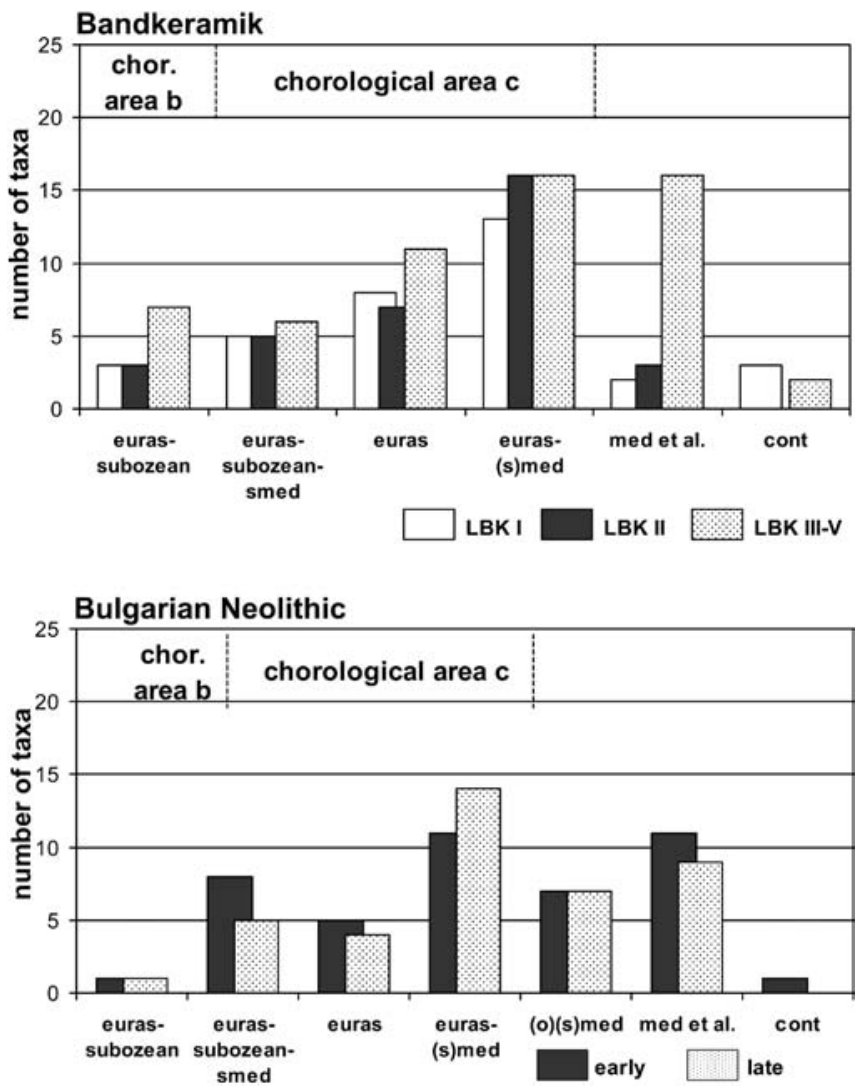

Fig. 12 Number of potential weed taxa of different chorological areas for the Bandkeramik and for the Bulgarian (Middle Neolithic excluded) Neolithic phases (see also Tables 7 and 8)

\section{Geographical origins of the potential weeds}

Finally, it is necessary to ask where the early Neolithic weed species originated geographically. To answer this question their actual centres of distribution "Pflanzengeographische Hauptverbreitung" according to Oberdorfer 2001), their chorological areas, are of interest. Figure 11 shows a map with the chorological areas of central Europe and adjacent areas after Oberdorfer (2001). The Bandkeramik sites discussed here are all situated in Oberdorfer's chorological area $\mathrm{b}$ which is defined as the region of the Subatlantic and Eurasiatic-Suboceanic species. His area c to the east and south of area $\mathrm{b}$ - is the Eurasiatic area where the Bulgarian Neolithic sites are situated. Tables 7 and 8 show, among others, the chorological areas of our potential weed species. The results are summarized in Fig. 12.

We can state that most Bandkeramik potential weeds and many of the Bulgarian Neolithic weeds were introduced with seeds into the fields and settlement sites from elsewhere. There is again no visible chronological development concerning the species of the early and late Bulgarian Neolithic sites. In contrast there is a strong increase of Mediterranean species during the Bandkeramik phases III-V (Fig. 12). More introduced species per site-especially Mediterranean ones-occur from Bandkeramik phase II onwards (without figure).
In this context Papaver somniferum, the western Mediterranean opium poppy, (see above) and possibly Vicia faba, the Mediterranean Celtic bean (Buxó 2004), which have been found at later Bandkeramik sites (Fig. 13), have to be remembered. These archaeobotanical phenomena still have to be connected with an archaeological counterpart to explain these new external influences. New waves of immigrants in the second half of the Bandkeramik period could be a possible explanation (Kreuz in press a).

\section{Conclusion}

The agricultural system of the Bulgarian Neolithic culture is based on 10 crop species (Fig. 13). Naked wheat and barley are higher yielding than emmer and einkorn, which are the only Bandkeramik cereals. However, they need more nitrogen than the hulled wheats, and naked wheat needs more careful weeding (Körber-Grohne 1988; Kreuz in press b). The characteristics of these additional cereals therefore have important consequences for a cultivation system. The additional pulses of the Bulgarian Neolithic, Cicer arietinum, Lathyrus sativus/cicera and Vicia ervilia also have special demands of cultivation.

Different dietary customs can be derived from the different crops: barley and naked wheat have a different taste and other requirements of processing and preparation than emmer and einkorn. The number of pulse species in the Bulgarian Neolithic might indicate that they were a certain substitute for meat in the diet.

The earliest Bandkeramik cultivation system with only five species was different from the neighbouring Starčevo, Körös, Cris cultures and the Bulgarian Neolithic. We could speculate whether manpower was a problem for Bandkeramik groups, which later even led to a time-saving change in lithic technology and harvest technique (see above). On the other hand there might also have been other priorities concerning parts of the agricultural system.

The weed assemblages let us assume that ear-plucking remained an important harvesting method throughout the Bulgarian Neolithic. At least some of the cereals were grown as winter crops there. In contrast the sowing time of the Bandkeramik farmers-as indicated by the weeds-points to (at least mainly, more likely exclusively) summer crop cultivation. In this case the fields could be grazed after harvest until the next spring. This would have been useful for the farmers if they put more emphasis on stock breeding.

Comparing the two cultivation systems, the Bulgarian Neolithic system seems more time-consuming than that of the Bandkeramik. This has important social implications. Social differences between the Bulgarian Neolithic and Bandkeramik are also indicated by different settlement structures and house types (see above).

To summarize, we can state that an important agricultural and social change of early Neolithic subsistence occurred somewhere in the transition area from eastern to western Hungary. It took several centuries until cultiva- 
Fig. 13 Charred plant remains from Bandkeramik sites in Hessen (Germany) and from Bulgarian Neolithic sites. Hessen: 1Triticum monococcum dorsal, L central grain $5.6 \mathrm{~mm}$, AK41EBN; 2Hordeum vulgarel distichon dorsal, L4.9 mm, AK1BB; 3Triticum dicoccum dorsal, L central grain $6.1 \mathrm{~mm}$, AK99US1; 4Triticum monococcum lateral, L5.6 mm, AK41EBN; 5Secale cereale dorsal, L4.9 mm, AK1BB; 6Panicum miliaceum dorsal, L1.5 mm, AK3 GO; 7Triticum dicoccum lateral, L lower grain $5.7 \mathrm{~mm}$, AK41EBN; 8Vicia ervilia, L3.6 mm, AK99US1; 9Vicia faba lateral, L4.5 mm, AK1 BB; 10Lens culinaris, L2.1 mm, AK134 NM; 11Pisum sativum, L3.1 mm, AK76WINI; 12Linum usitatissimum, L2.95 mm, AK134NM; 13Papaver somniferum, L0.9 mm, AK134NM; Bulgaria: 14Cicer arietinum, D4.1 mm; 15 Coriandrum sativum, L3.05 mm; 16Triticum sp., new type, spikelet ventral, L2.6 mm; 17Triticum sp., new type, spikelet dorsal, L2.6 mm; 18Hordeum distichon rachis fragment, L3.0 mm; 19Triticum aestivum s.l./durum/turgidum rachis fragment, L1.8 mm. Kapitan Dimitrievo 14, 15, 18; Karanovo $16,17,19$. For site codes and dating see Tables 2 and 3
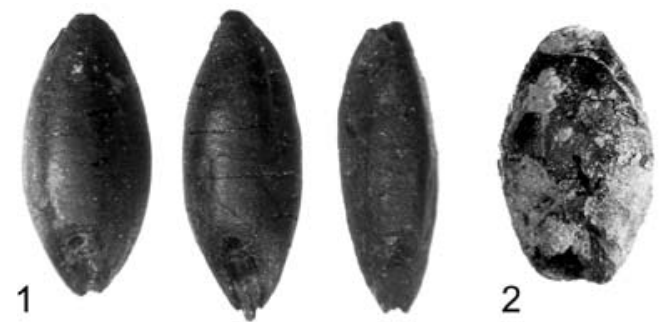

2

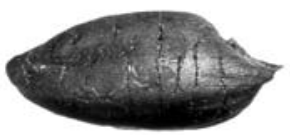

4

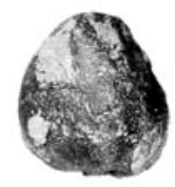

8

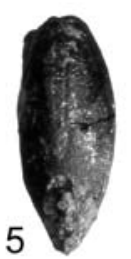

6
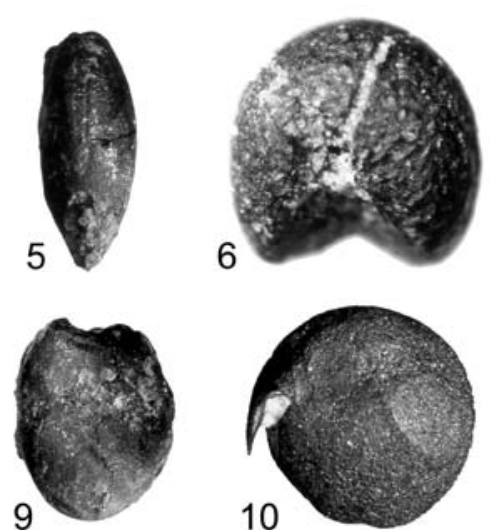

10
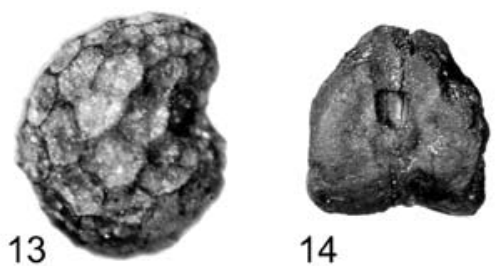

14

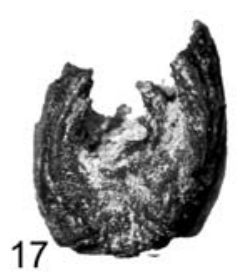

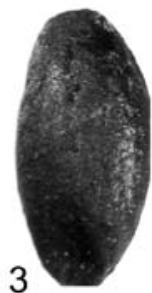
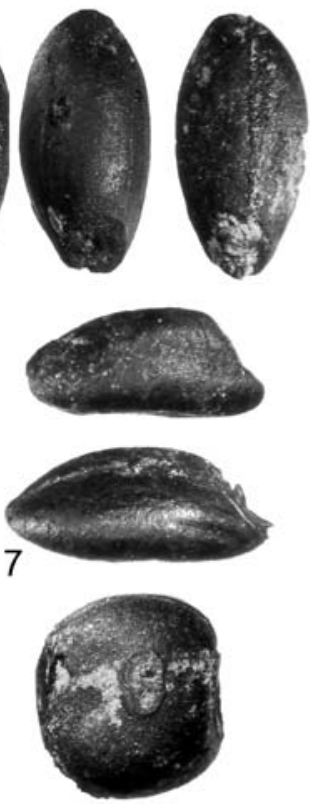

11

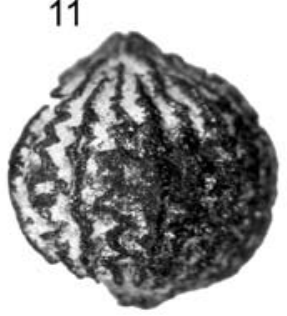

15
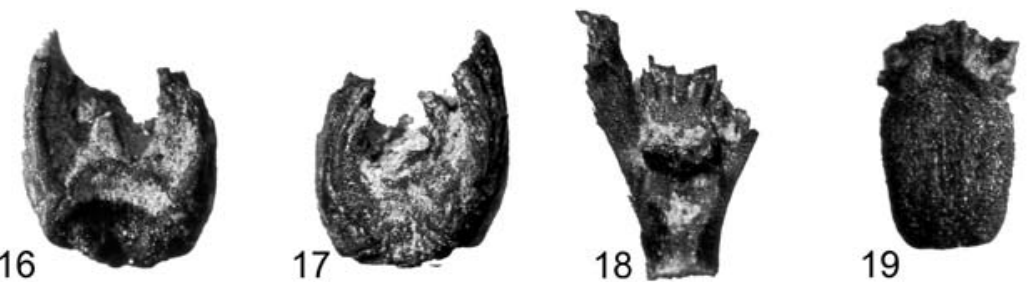

tion of barley and naked wheat crossed the rivers Tisza and Danube. In western central Europe this was the beginning of the middle Neolithic with the rising of the Großgartach and the Rössen Cultures, including - among others-settlement structures, technologies and ritual practices different from the Bandkeramik ones (Eisenhauer 1999; Lüning 2000, p 16ff.). The background of this delayed adaptation of two important cereals-Hordeum sp. (barley) and Triticum aestivum s.l./durum/turgidum (naked wheat)-in western central Europe is not yet understood. Future archaeobiological and archaeological work-especially in the key area of Hungary - is therefore urgently needed.

Acknowledgements Our warmest thanks to F. Bittmann, A. Bogaard, K. Borojevič, D. Filipovič, F. Gyulai, M. Kohler-Schneider, D. Kučan, E. Margaritis, R. Neef, T. Popova and S.M. Valamoti for their unpublished data from Austria, Bulgaria, Greece, Hungary, former Yugoslavia and Turkish Thrace. We thank the Deutsche Forschungsgemeinschaft for funding the project "Archaeobotanical investigations of Early, Middle and Late Neolithic landscape development and agricultural systems in Hesse, Germany, and adjacent areas" (KR1569/2-4), the referees S. Jacomet and G. Jones for helpful remarks, M. Elibal, A. Posluschny and H. von Schlieben for the help with the scans, maps and photographs and James Greig for improving our English

\section{References}

Arbogast, R.-M., Jeunesse, C., Schibler, J. (2001). Rolle und Bedeutung der Jagd während des Frühneolithikums Mitteleuropas (Linearbandkeramik 5500-4900 v. Chr.) Internationale Archäologie: Arbeitsgemeinschaft, Symposium, Tagung, Kongress 1. Leidorf, Rahden/Westfalen

Arnaudov, N. (1936). Über prähistorische subrecente Pflanzenreste aus Bulgarien. Trudove na bâlgarskoto prirodoizpitatelno druzhestwo, 17, 26-31

Arnaudov, N. (1938). Rastitelni materiali ot predistoričeskoto selište do s. Karanovo (Novozagorsko) [Pflanzenreste aus der prähistorischen Siedlung Karanovo in Südbulgarien] (in Bulgarian with German summary). Annuaire de l'université de 
Sofia "St. Kliment Ohridski", Faculté Physicomathematique, 3-Sciences naturelles, 34, 79-98

Arnaudov, N. (1949). Predistoricheski rastitelni materiali [Prehistoric plant materials]. Annuaire de l'université de Sofia "st. Kliment Ohridski", Faculté de Sciences, 3-Sciences Naturelles, 45, 68-81

Arnaudov, N., Vassileva, P. (1948). Prinos za izuchavane na predistoricheskite limeci [Contribution to the study of the praehistoric hulled wheats]. Annuaire de l'université de Sofia "St. Kliment Ohridski", Faculté des Sciences, 3-Sciences Naturelles, 44, 108-111

Bakels, C.C. (1978). Four Linearbandkeramik settlements and their environment: a palaeoecological study of Sittard, Stein, Elsloo und Hienheim. Analecta Praehistorica Leidensia 11. University Press, Leiden

Bakels, C.C. (1982). Der Mohn, die Linearbandkeramik und das westliche Mittelmeergebiet. Archäologisches Korrespondenzblatt, 12, 11-13

Bakels, C.C. (1991). Tracing crop processing in the Bandkeramik culture. In: Renfrew, J. (ed) New light on early farming. Recent developments in Palaeoethnobotany. Edinburgh University Press, Edinburgh, pp 281-288

Bakels, C.C., Rousselle, R. (1985). Restes botaniques et agriculture du Néolithique ancien en Belgique et aux Pays-Bas. Helinium, $25,37-57$

Bánffy, E. (2001). Siedlungsgeschichte Südwesttransdanubiens im Neolithikum und Chalkolithikum. In: Lippert, A., Schultz, M., Shennan, S., Teschler-Nicola, M. (eds) Mensch und Umwelt während des Neolithikums und der Frühbronzezeit in Mitteleuropa. Internationale Archäologie-Arbeitsgemeinschaft, Symposium, Tagung, Kongress, 2, 171-179

Behre, K.-E., Jacomet, S. (1991). The ecological interpretation of archaeobotanical data. In: Zeist, W. van, Wasylikowa, K., Behre, K.-E. (eds) Progress in Old World Palaeoethnobotany. Balkema, Rotterdam Brookfield, pp 81-108

Benecke, N., Ninov, L. (2002). Zur Nahrungswirtschaft der neolithischen Bevölkerung im Gebiet des heutigen Bulgariens nach archäozoologischen Befunden. In: Lichardus-Itten, M., Lichardus, J., Nikolov, V. (eds) Beiträge zu jungsteinzeitlichen Forschungen in Bulgarien. Saarbrücker Beiträge zur Altertumskunde, 74. Habelt, Bonn 2002, pp 555-573

Beug, H.-J. (1986). Vegetationsgeschichtliche Untersuchungen über das Frühe Neolithikum im Untereichsfeld, Landkreis Göttingen. In: Behre, K.-E. (ed) Anthropogenic indicators in pollen diagrams. Balkema, Rotterdam, Boston pp 115-124

Beug, H.-J. (1992). Vegetationsgeschichtliche Untersuchungen über die Besiedlung im Unteren Eichsfeld, Landkreis Göttingen, vom frühen Neolithikum bis zum Mittelalter. Neue Ausgrabungen und Forschungen in Niedersachsen, 20, 261-339

Beug, H.-J., Henrion, I., Schmüser, A. (1999). Landschaftsgeschichte im Hochharz. Die Entwicklung der Wälder und Moore seit dem Ende der letzten Eiszeit. Papierflieger Verlag, Clausthal-Zellerfeld

Bogaard, A. (2004). Neolithic farming in Central Europe. Routledge, London

Bogaard, A., Bending, J., Jones, G. (2004). Ecsegfalva, chap 8. The charred remains of crops, weeds and other plants (unpublished manuscript 2004)

Bohn, U., Gollub, G., Hettwer, C., Neuhäuslová, Z., Schlüter, H., Weber, H. (2003). Karte der natürlichen Vegetation Europas 1:2500000. Landwirtschaftsverlag, Bonn

Borojevič, K. (1998). The relations among farming practices, landownership and social stratification in the Balkan Neolithic period. $\mathrm{PhD}$ Thesis Washington University, Saint Louis, Missoury

Borojevič, K., Filipovič, D. (in press). Preliminarni rezultati arheobotnickih istrazivanja sa projecta Vinča (1998-2003) [Preliminary archaeobotanical results of the Vinča project]. Belgrade

Bouzek, J. (2001). Klimatische Entwicklung im Äneolithikum und in der Frühbronzezeit in Böhmen und Mähren. In: Lippert, A., Schultz, M., Shennan, S., Teschler-Nicola, M. (eds) Mensch und Umwelt während des Neolithikums und der Frühbronzezeit in Mitteleuropa. Internationale Archäologie-Arbeitsgemeinschaft, Symposium, Tagung, Kongress, 2, 21-26

Božilova, E., Filipova, M., Filipovich, L., Tonkov, S. (1996). Bulgaria. In: Berglund, B., Birks, H.J.B., Ralska-Jasiewiczowa, M., Wright, H.E. (eds), Palaeoecological Events During the Last 15000 years: regional syntheses of palaeoecological studies of lakes and mires in Europe. Wiley, Chichester New York Brisbone Toronto Singapure, pp 701-728

Buxó, R. (2004). Eines i feines del camp a Catalunya. L'estudi de l'agricultura a través de l'arqueologia. Museu d'Arqueologia de Catalunya, Girona

Cârciumaru, M. (1995). Paleoethnobotanica. Studii in preistoria si protoistoria Romaniei. Istoria agriculturii din Romania. [Paleoethnobotany. Studies on the prehistory of Romania. History of the agriculture of Romania]. Bucuresti

Cârciumaru, M., Monah, F. (1987). Determinations paleobotaniques pour les cultures Precucuteni et Cucuteni, La civilisation de Cucuteni en contexte Européen. Université Al.I. Cuza, Iasi, pp 167-174

Davis, B., Brewer, S., Stevenson, A., Guiot, J., Data Contributors (2003). The temperature of Europe during the Holocene reconstructed from pollen data. Quaternary Science Reviews, 22, $1701-1716$

Dennell, R. (1978). Early farming in South Bulgaria from the VIth to the IIIth Millenia B.C. BAR International Series, 45. Oxford University Press, Oxford

Dotcheva, E. (1990). Plant macrorest research of Early Neolithic dwelling in Slatina. Studia Praehistorica, 10, 86-90

Eckert, J., Eisenhauer, U., Zimmermann, A. (eds) (2003). Archäologische Perspektiven. Analysen und Interpretationen im Wandel. Internationale Archäologie, Studia honoraria, 20. Leidorf, Rahden/Westfalen

Egger, H. (1997). Geowissenschaftliche Aspekte zur Lage von Tell Karanovo. In: Hiller, S., Nikolov, V. (eds) Karanovo 1. Österreichisch-Bulgarische Ausgrabungen und Forschungen in Karanovo. Die Ausgrabungen im Südsektor 1984-1992. Berger \& Söhne, Salzburg Sofia, pp 11-18

Eisenhauer, U. (1999). Kulturwandel als Innovationsprozeß: Die fünf großen "W" und die Verbreitung des Mittelneolithikums in Südwestdeutschland. Archäologische Informationen, 22, 215239

Filipovitch, L. (1996). The Holocene plant succession in the mountains of Northwestern Bulgaria. Phytologia Balcanica, 2, $54-60$

Filipovitch, L., Lazarova, M. (2001). Composition and trends in the development of vegetation in the Western Rhodopes (Southwest Bulgaria) during the Late Glacial and Holocene. Phytologia Balcanica, 7, 167-180

Georgiev, G. (1961). Kulturgruppen der Jungstein- und Kupferzeit in der Ebene von Thrakien (Südbulgarien). In: Böhm, J., Laet, S. de (eds) L'europe à la fin de l'Âge du Pierre. Prag, pp 67-79

Georgiev, G.I. (1981). Erforschung des Neolithikums in der Thrakischen Tiefebene. In: Busch, R. (ed) Jungsteinzeit in Bulgarien. Komitee für Kultur, Sofia, pp 15-22

Görsdorf, J., Bojadžiev, J. (1996). Zur absoluten Chronologie der bulgarischen Urgeschichte. Berliner 14C-Datierungen von bulgarischen archäologischen Fundplätzen. Eurasia Antiqua, 2, $105-173$

Groenman-van Waateringe, W. (1970). Hecken im westeuropäischen Frühneolithikum. Berichten van de Rijksdienst voor het Oudheidkundig Bodemonderzoek, 20-21, 295-299

Gronenborn, D. (1997). Silexartefakte der ältestbandkeramischen Kultur. Universitätsforschungen zur prähistorischen Archäologie, 37. Habelt, Bonn

Grooth, M.E.T. de (2003). "They do things differently there". Flint working at the Early Bandkeramik settlement of Geleen-Janskamperveld (The Netherlands). In: Eckert, J., Eisenhauer, U., Zimmermann, A. (eds) Archäologische Perspektiven. Analysen und Interpretationen im Wandel. Internationale Archäologie, Studia honoraria, 20, 401-406 
Haas, J.N., Richoz, I., Tinner, W., Wick, L. (1998). Synchronous Holocene climatic oscillations recorded on the Swiss Plateau and at timberline in the Alps. The Holocene, 8, 301-309

Hiller, S. (1993). Neolithische Megaronhäuser. In: Nikolov, V. (ed) Prähistorische Funde und Forschungen. NEDA, Sofia, pp 111120

Hillman, G.C. (1981). Reconstructing crop husbandry practices from charred remains of crops. In: Mercer, R. (ed) Farming practice in British Prehistory. Edinburgh University Press, Edinburgh, pp 123-162

Hopf, M. (1973). Frühe Kulturpflanzen aus Bulgarien. Jahrbuch des Römisch-Germanischen Zentralmuseums Mainz, 20, 1-47

Hopf, M. (1988). Frühneolithische Kulturpflanzen aus PolajnicaPalteau bei Targoviste (Bulgarien). Studia Praehistorica, 8, 3436

Hopf, M. (1991). South and Southwest Europe. In: Zeist, W. van, Wasylikowa, K., Behre, K.-E. (eds) Progress in Old World Palaeoethnobotany. Balkema, Rotterdam Brookfield, pp 241278

Hormes, A., Müller, B.U., Schlüchter, C. (2001). The Alps with little ice: evidence for eight Holocene phases of reduced glacier extent in the Central Swiss Alps. The Holocene, 11, 255-265

Horvat, I., Glavač, V., Ellenberg, H. (1974). Vegetation Südosteuropas. Gustav Fischer, Stuttgart

Hubbard, R., Housley, R. (2000). The agriculture in prehistoric Servia. In: Ridley, C., Wardle, K., Mould, C.A. (eds), Servia I: Anglo-Hellenic rescue excavations 1971-73. British School at Athens, Supplementary Volume, 32. Oxbow Books, Oxford, pp 330-336

Huttunen, A., Huttunen, R.-L., Vasary, Y., Panovska, H., Božilova, E. (1992). Late glacial and Holocene history of flora and vegetation in the Western Rhodopes Mountains, Bulgaria. Acta Botanica Fennica, 144, 63-80

Ibánez, J.J., González Urquijo, J.E., Peña-Chocarro, L., Beugnier, V. (2001). Harvesting without sickles. Neolithic examples from humid mountain areas. In: Beyries, S., Petrequin, P. (eds) Ethno-archaeology and its transfers. BAR International Series, 983. Archaeopress, Oxford, pp 23-36

Jones, G., Halstead, P. (1995). Maslins, mixtures and monocrops. On the interpretation of archaeobotanical crop samples of heterogeneous composition. Journal of Archaeological Science, 22, 103-114

Jones, G., Valamoti, S., Charles, M. (2000). Early Crop diversity: a "new" glume wheat from northern Greece. Vegetation History and Archaeobotany, 9, 133-146

Jones, G., Bogaard, A., Halstead, P., Charles, M., Smith, H. (1999). Identifying the intensity of crop husbandry practices on the basis of weed floras. The Annual of the British School at Athens, 94, 167-189

Kalicz, N. (2001). Zusammenhänge zwischen dem Siedlungswesen und der Bevölkerungszahl während des Spätneolithikums in Ungarn. In: Lippert, A., Schultz, M., Shennan, S., TeschlerNicola, M. (eds) Mensch und Umwelt während des Neolithikums und der Frühbronzezeit in Mitteleuropa. Internationale Archäologie-Arbeitsgemeinschaft, Symposium, Tagung, Kongress, 2, 153-164

Kalis, A.J., Merkt, J., Wunderlich, J. (2003). Environmental changes during the Holocene climatic optimum in Central Europe-human impact and natural causes. Quaternary Science Reviews, 22, 33-79

Kästner, A., Jäger, E., Schubert, R. (2001). Handbuch der Segetalpflanzen Mitteleuropas. Springer, Wien New York

Kind, C.-J. (1997). Die letzten Wildbeuter. Henauhof Nord II und das Endmesolithikum in Baden-Württemberg. Forschungen und Berichte zur Vor- und Frühgeschichte in Baden-Württemberg, 39. Theiss, Stuttgart

Knörzer, K.-H. (1991). Deutschland nördlich der Donau. In: Zeist, W. van, Wasylikowa, K., Behre, K.-E. (eds) Progress in Old World Palaeoethnobotany. Balkema, Rotterdam Brookfield, pp 189-206

Knörzer, K.-H. (1997). Botanische Untersuchung von 16 neolithischen Siedlungsplätzen im Bereich der Aldenhovener
Platte. In: Lüning, J. (ed) Studien zur neolithischen Besiedlung der Aldenhovener Platte und ihrer Umgebung. Rheinische Ausgrabungen, 43. Rheinland-Verlag, Köln Bonn, pp 648-684

Körber-Grohne, U. (1988). Nutzpflanzen in Deutschland. Theiss, Stuttgart

Kohler-Schneider, M. (2003). Contents of a storage pit from late Bronze Age Stillfried, Austria: another record of the "new" glume wheat. Vegetation History and Archaeobotany, 12, 105111

Kopralev, I.E. (2002). Geography of Bulgaria. Physical Geography. Socio-Economic Geography. ForComPublishers, Sofia

Kovachev, G., Georgiev, G. (2002). Zhivotinski kosten material of selishtnata mogila [Animal bone material from the multy-layer settlement]. In: Radunčeva, A., Macanova, V., Gacov, I., Kovacev, G., Georgiev, G., Tschakalova, E., Božilova, E. (eds), Neolitnoto selishte do grad Rakitovo [Neolithic settlement near Rakitovo]. Razkopki i Proucvanija, 29. Gal-Iko Publisher, Sofia, pp 171-190

Kreuz, A. (1988). Holzkohle-Funde der ältestbandkeramischen Siedlung Friedberg-Bruchenbrücken: Anzeiger für BrennholzAuswahl und lebende Hecken? Forschungen und Berichte zur Vor- und Frühgeschichte in Baden-Württemberg. In: Küster, H. (ed) Der prähistorische Mensch und seine Umwelt. Forschungen und Berichte zur Ur- und Frühgeschichte in Baden-Württemberg, 31, 39-153

Kreuz, A. (1990). Die ersten Bauern Mitteleuropas - eine archäobotanische Untersuchung zu Umwelt und Landwirtschaft der Ältesten Bandkeramik. Analecta Praehistorica Leidensia, 23. University Press, Leiden

Kreuz, A. (1992). Charcoal from ten early Neolithic settlements in Central Europe and its interpretation in terms of woodland management and wildwood resources. In: Vernet, J.-L. (ed) Les charbons de bois, les anciens écosystèmes et le rôle de l'homme. Charcoal, ancient ecosystems and human impact. Bulletin de la Société Botanique de France, 139, 383-394

Kreuz, A. (1993). Einheimische oder fremde Pflanzen? Uberlegungen zur Herkunft "potentieller Unkräuter" und ihrer Verbreitung zur Zeit der Bandkeramik. In: Kalis, A.J., MeurersBalke, J. (eds) 7000 Jahre bäuerliche Landwirtschaft: Entstehung, Erforschung, Erhaltung. Archaeo-Physika, 13, 23-33

Kreuz, A. (1995). "On-site and off-site data-interpretative tools for a better understanding of Early Neolithic environments. In: Kroll, H., Pasternak, R. (eds) Res archaeobotanicae-9th Symposium IWGP. Oetker-Voges-Verlag, Kiel, pp 117-134

Kreuz, A. (in press a). Archaeobotanical perspectives on the beginning of agriculture north of the Alps. In: Colledge, S., Conolly, J. (eds) Archaeobotanical perspectives on the origin and spread of agriculture in southwest Asia and Europe. UCL Press, London

Kreuz, A. (in press b). Landwirtschaft im Umbruch? Archäobotanische Untersuchungen zu den Jahrhunderten um Christi Geburt in Hessen und Mainfranken. Bericht der RömischGermanischen Kommission 80 (2004)

Kreuz, A., Boenke, N. (2002). The presence of two-grained einkorn at the time of the Bandkeramik culture. Vegetation History and Archaeobotany, 11, 233-240

Kreuz, A., Schäfer, E. (2002). A new archaeobotanical database programme. Vegetation History and Archaeobotany, 11, 177179

Kroll, H. (1991). Südosteuropa. In: Zeist, W. van, Wasylikowa, K., Behre, K.-E. (eds) Progress in Old World Palaeoethnobotany. Balkema, Rotterdam Brookfield, pp 161-178

Lichardus-Itten, M., Demoule, J.-P., Perničeva, L., Grebska-Kulova, M., Kulov, I. (2002). The site of Kovačevo and the beginnings of the Neolithic period in Southwestern Bulgaria. In: Lichardus-Itten, M., Lichardus, J., Nikolov, V. (eds) Beiträge $\mathrm{zu}$ jungsteinzeitlichen Forschungen in Bulgarien. Saarbrücker Beiträge zur Altertumskunde 74. Habelt, Bonn, pp 99-158

Lichardus-Itten, M., Lichardus, J. (2003). Strukturelle Grundlagen zum Verständnis der Neolithisierungsprozesse in Südost- und Mitteleuropa. In: Jerem, E., Raczky, P. (eds) Morgenrot der 
Kulturen. Frühe Etappen der Menschheitsgeschichte in Mittelund Südosteuropa. Budapest, pp 61-81

Liese-Kleiber, H. (1997). Erste Pollenanalysen und C-14-Daten aus den mesolithischen Lagerplätzen Henauhof Nord I und II am Federsee. In: Kind, C.-J., Die letzten Wildbeuter. Henauhof Nord II und das Endmesolithikum in Baden Württemberg. Materialhefte zur Archäologie in Baden-Württemberg, 39, 212232

Lisitzina, G., Filipovitch, L. (1980). Palaeoethnobotanical findings in the Balkan Peninsula. Studia Praehistorica, 4, 5-90

Litt, T. (1990). Pollenanalytische Untersuchungen im Allertal bei Eilsleben, Kr. Wanzleben, und ihre Aussagemöglichkeit zur Vegetationsentwicklung während des Frühneolithikums (Vorläufige Mitteilung). Jahresschrift für mitteldeutsche Vorgeschichte, 73, 49-55

Lüning, J. (1991). Frühe Bauern in Mitteleuropa im 6. und 5. Jahrtausend v. Chr. Jahrbuch des Römisch-Germanischen Zentralmuseums Mainz, 35(1988), 2-93

Lüning, J. (2000). Steinzeitliche Bauern in Deutschland. Die Landwirtschaft im Neolithikum. Universitätsforschungen zur prähistorischen Archäologie, 58. Habelt, Bonn

Lüning, J., Kloos, U., Albert, S. (1989). Westliche Nachbarn der bandkeramischen Kultur: La Hoguette und Limburg. Germania, 67, 355-393

Magny, M. (1998). Reconstruction of Holocene lake-level changes in the French Jura: methods and results. In: Harrison, S.P., Frenzel, B., Huckriede, U., Weiß, M.M. (eds) Palaeohydrology as reflected in lake-level changes al climatic evidence for Holocene times. Paläoklimaforschung/Palaeoclimate Research 25. Gustav Fischer, Stuttgart, pp 67-85

Maise, C. (1998). Archäoklimatologie. Vom Einfluß nacheiszeitlicher Klimavariabilität in der Ur- und Frühgeschichte. Jahrbuch der Schweizerischen Gesellschaft für Urund Frühgeschichte, 81, 197-235

Marinova, E. (1999). Archaeobotanical study of Early and Late Neolithic materials (in Bulgarian with English summary). In: Nikolov, V. (ed), Tell Kapitan Dimitrievo. Ausgrabungen 1998-1999, Sofia-Pestera, pp 123-130

Marinova, E. (2000). Analyse des macrorestes botaniques des campagnes 1998 et 1999. In: Demoule, J.-P., Lichardus-Itten, M. (eds) Kovacevo. Foullies neolithiques franco-bulgares dans la vallée du Strymon. 14. Rapport annuel, Université de Paris I. Paris pp 32-38

Marinova, E.M. (2001). Vergleichende paläoethnobotanische Untersuchung zur Vegetationsgeschichte und zur Entwicklung der prähistorischen Landnutzung in Bulgarien. PhD Thesis, University of Bonn. Bonn

Marinova, E., Tchakalova, E., Stoyanova, D., Grozeva, S., Doĉeva, E. (2002). Ergebnisse archäobotanischer Untersuchungen aus dem Neolithikum und Chalcolithikum in Südwestbulgarien. Archaeologia Bulgarica, 6(3), 1-11

Meier-Arendt, W. (1966). Die Bandkeramische Kultur im Untermaingebiet. Veröffentlichungen des Amtes für Bodendenkmalpflege im Regierungsbezirk Darmstadt 3, Darmstadt

Monah, F., Monah, D. (1996). Macrorestes vegetaux découverts dans les niveaux Cucuteni A2 et B1 de Poduri - "Dealul Ghindaru". Memoria Antiquitatis, 2, 49-62

Nikolov, V. (2000). Neolithische Keramikkomplexe in Thrakien. In: Hiller, S., Nikolov, V. (eds) Karanovo III. Beiträge zum Neolithikum in Südosteuropa. Akten des internationalen Symposiums 'Tell Karanovo 1947-1997', Karanovo 1997. Phoibos, Wien, pp 11-19

Nikolov, V. (2002). Problems of cultural development and chronology in the Early Neolithic of West Bulgaria. In: Lichardus-Itten, M., Lichardus, J., Nikolov, V. (eds) Beiträge zu jungsteinzeitlichen Forschungen in Bulgarien. Saarbrücker Beiträge zur Altertumskunde, 74. Habelt, Bonn, pp 159-163

Nikolov, V. (2004). Dynamics of the cultural processes in Neolithic Thrace. In: Nikolov, V., Bâčvarov, K., Kalchev, P. (eds) Praehistoric Thrace. Proceedings of the International Symposium, Stara Zagora, 30.09.-04.10.2003. Bulgarian Academy of Sciences, Sofia, pp 18-25
Ninov, L. (1992). Archäozoologische Untersuchungen von den Faunaresten im Haus (in Bulgarian with German summary). In: Nikolov, V. (ed), Frühneolithisches Haus in Slatina. Bulgarische Akademie der Wissenschaften, Sofia, pp 152-156

Ninov, L. (1999). Archaeozoology (in Bulgarian with English summary). In: Nikolov, V. (ed) Tell Kapitan Dimitrievo. Ausgrabungen 1998-1999. Sofia-Pestera, pp 131-136

Ninov, L. (2002). Archäozoologische Untersuchungen. In: Hiller, St., Nikolov, V. (eds) Karanovo II. Österreichisch-Bulgarische Ausgrabungen und Forschungen in Karanovo. Die Ausgrabungen in O 19. Phoibos Verlag, Wien, pp 187-195

Ninov, N. (2002). Soils. In: Kopralev, I. (ed) Geography of Bulgaria. Physical geography. Socio-Economic Geography. ForComPublishers, Sofia, pp 227-316

Oberdorfer, E. (1990), (2001). Pflanzensoziologische Exkursionsflora für Deutschland und angrenzende Gebiete, 6th, 8th ed. Ulmer, Stuttgart

Parzinger, H. (1993). Studien zur Chronologie und Kulturgeschichte der Jungstein-, Kupfer- und Frühbronzezeit zwischen Karpaten und Mittlerem Taurus. Teil 1. Römisch-Germanische Forschungen, 52. Philipp von Zabern, Mainz

Perles, C. (2001). The Early Neolithic in Greece. The first farming communities in Europe. Cambridge World Archaeology. Cambridge University Press, Cambridge

Popova, T. (1992). Analyse carpologique. In: Demoule, J.-P., Lichardus-Itten, M. (eds) Kovačevo. Foullies néolithiques francobulgares dans la vallée du Strymon. 8. Rapport annuel, Université de Paris I. Paris, pp 21-23

Popova, T. (1995a). Arheobotaniceski materiali ot kasnoneolitno zilishte w selishtanata mogila Karanovo [Archaeobotanical materials from an Late Neolithic dwelling in tell Karanovo]. Arheologia, 4, 27-28

Popova, T. (1995b). Plant remains from Bulgarian prehistory. In: Bailey, D.W., Panayotov, I. (eds) Prehistory of Bulgaria. Monographs in World Archaeology. Prehistory Press, Madison, Wisconsin, pp 193-207

Raetzel-Fabian, D. (1988). Die ersten Bauernkulturen. Jungsteinzeit in Nordhessen. Vor- und Frühgeschichte im Hessischen Landesmuseum in Kassel, 2. Staatliche Kunstsammlungen, Kassel

Renfrew, J. (1973). Palaeoethnobotany. The prehistoric food plants of the Near East and Europe. Methuen, London

Renfrew, J. (1979). The first farmers in South East Europe. In: Körber-Grohne, U. (ed) Festschrift Maria Hopf. ArchaeoPhysika, 8, 243-265

Reynolds, P. (1985). Carbonized seed, crop yield, weed infestation and harvesting techniques of the Iron Age. In: Gast, M., Sigaut, F., Beutler, C. (eds) Les techniques de conservation des graines à long terme, 3. CNRS Editions, Paris, pp 397-407

Reynolds, P.J. (1993). Zur Herkunft verkohlter Getreidekörner in urgeschichtlichen Siedlungen-Eine alternative Erklärung. In: Kalis, A.J., Meurers-Balke, J. (eds) 7000 Jahre bäuerliche Landwirtschaft: Entstehung, Erforschung, Erhaltung. ArchaeoPhysika, 13, 187-206

Schäfer, M. (1996). Pollenanalysen an Mooren des Hohen Vogelsberges (Hessen). Beiträge zur Vegetationsgeschichte und anthropogenen Nutzung eines Mittelgebirges. Dissertationes Botanicae, 265. J. Cramer, Berlin

Schlichterle, H. (1992). Jungsteinzeitliche Erntegeräte am Bodensee. Plattform, Zeitschrift des Vereins fur Pfahlbau und Heimatkunde, 1, 24-44

Schmidt, B., Gruhle, W. (2003). Niederschlagsschwankungen in Westeuropa während der letzten 8000 Jahre. Versuch einer Rekonstruktion mit Hilfe eines neuen dendrochronologischen Verfahrens (Grad der Wuchshomogenität). Archäologisches Korrespondenzblatt, 33, 281-300

Schroeder, F.-G. (1969). Zur Klassifizierung der Anthropochoren. Vegetatio, 16, 225-238

Schroeder, F.-G. (1974). Zu den Statusangaben bei der floristischen Kartierung Mitteleuropas. Göttinger Floristische Rundbriefe, 8 , $71-79$ 
Schweizer, A. (2001). Archäopalynologische Untersuchungen zur Neolithisierung der nördlichen Wetterau/Hessen. Dissertationes Botanicae, 350. Cramer, Berlin

Sielmann, B. (1971). Die frühneolithische Besiedlung Mitteleuropas. In: Schwabedissen, H. (ed) Die Anfänge des Neolithikums vom Orient bis Nordeuropa, Teil V a: Westliches Mitteleuropa. Fundamenta, Monographien zur Urgeschichte A 3. Böhlau, Köln Wien, pp 1-65

Spurk, M., Leuschner, H.H., Baillie, M.G.L., Briffa, K.R., Friedrich, M. (2002). Depositional frequency of German subfossil oaks: climatically and non-climatically induced fluctuations in the Holocene. The Holocene, 12, 707-715

Stäuble, H. (1995). Radiocarbon dates of the earliest Neolithic in Central Europe. In: Cook, G.T., Harkness, D.D., Miller, B.F., Scott, E.M. (eds) Proceedings of the 15th International C-14 Conference. Radiocarbon, 37, 227-237

Stefanova, I., Ammann, B. (2003). Lateglacial and Holocene vegetation belts in the Pirin Mountains (southwestern Bulgaria). The Holocene, 13, 97-107

Stöckli, W. (2002). Absolute und relative Chronologie des Frühund Mittelneolithikums in Westdeutschland (Rheinland und Rhein-Main-Gebiet). Basler Hefte zur Archäologie, 1. Archäologie Verlag, Basel

Thanheiser, U. (1997). Botanische Funde. In: Hiller, S., Nikolov, V. (eds) Karanovo I. Österreichisch-Bulgarische Ausgrabungen und Forschungen in Karanovo. Die Ausgrabungen im Südsektor 1984-1992. Berger \& Söhne, Salzburg Sofia, pp 429-480

Thiébault, S. (1997). Resultats preliminares de l'analyse de charbons de bois. In: Demoule, J.-P., Lichardus-Itten, M. (eds), Kovačevo. Foullies neolithiques franco-bulgares dans la vallée du Strymon. 12. Rapport annuel, Université de Paris I. Paris, pp 44-46

Todorova, H. (1981). Das Neolithikum in Nordostbulgarien. In: Busch, R. (ed) Jungsteinzeit in Bulgarien. Komitee für Kultur, Sofia, pp 22-24

Todorova, H., Vaissov, I. (1993). The Neolithic in Bulgaria (Bulgarian with German and English summary). Nauka I Izkustvo, Sofia

Tonkov, S., Božilova, E. (1992). Palaeoecological investigation of Tschokljovo marsch (Konjavska Mountain). Annuaire de l'Université de Sofia "St. Kliment Ohridski", Faculté de Biologie, 2-Botany, 83, 5-16

Tschakalova, E., Božilova, E. (2002). Paleoecologichni i paleoetnobotanicni materiali ot selishtanat mogila do gr. Rakitovo
[Palaeoecological and paleoethnobotanical materials from the tell near town Rakitovo](in Bulgarian with German summary). In: Radunčeva, A. (ed) Neolitnoto selishte do grad Rakitovo [Neolithic settlement near Rakitovo]. Razkopki i Proucvanija, 29. Gal-Iko Publisher, Sofia, pp 192-201

Tschakalova, E., Sârbinska, E. (1986). Pflanzenreste aus der neolithischen Siedlung Kremenik bei Sapareva Banja. Studia Praehistorica, 8, 156-159

Valamoti, S.M. (2004). Plants and people in Late Neolithic and Early Bronze Age Northern Greece: an archaeobotanical investigation. BAR International Series, S1258. Archaeopress, Oxford

Valamoti, S.M., Jones, G. (in press). Plant diversity and storage at Mandalo, Macedonia, Greece: Archaeobotanical evidence from the Final Neolithic and Early Bronze Age. B. S. A. Annual of the British School of Athens

Veen, M. van der (1997). Environmental factors and the yield potential of ancient wheat crops. Journal of Archaeological Science, 24, 163-182

Velev, S. (2002). Climate regioning. In: Kopralev, I. (ed), Geography of Bulgaria. ForComPublishers, Sofia, pp 155-157

Wasylikowa, K., Cârciumaru, M., Hajnalová, E., Hartyányi, B.P., Pashkevich, G.A., Yanushevich, Z.V. (1991). East-Central Europe. In: Zeist, W. van, Wasylikowa, K., Behre, K.-E. (eds) Progress in Old World palaeoethnobotany. Balkema, Rotterdam, pp 207-240

Willerding, U. (1980). Zum Ackerbau der Bandkeramiker. In: Krüger, T., Stephan, H.-G. (eds) Beiträge zur Archäologie Nordwestdeutschlands und Mitteleuropas. Materialhefte zur Ur- und Frühgeschichte Niedersachsens, 16, 421-457

Zeist, W. van (1967). Palynologische Untersuchungen eines Torfprofils bei Sittard. Palaeohistoria, 6/7, 19-24

Zeist, W. van (1987). Some reflections on prehistoric field weeds. Palaeoecology of Africa and the surrounding islands, 18, 405427

Zeist, W. van (2003). Plant husbandry and vegetation of tell Gomolava, Vojvodina, Yugoslavia. Palaeohistoria, 43/44, 87-115

Zeist, W. van, Spoel-Walvius, M.R. van der (1980). A palynological study of the late-glacial and the postglacial in the Paris basin. Palaeohistoria, 22, 67-109 